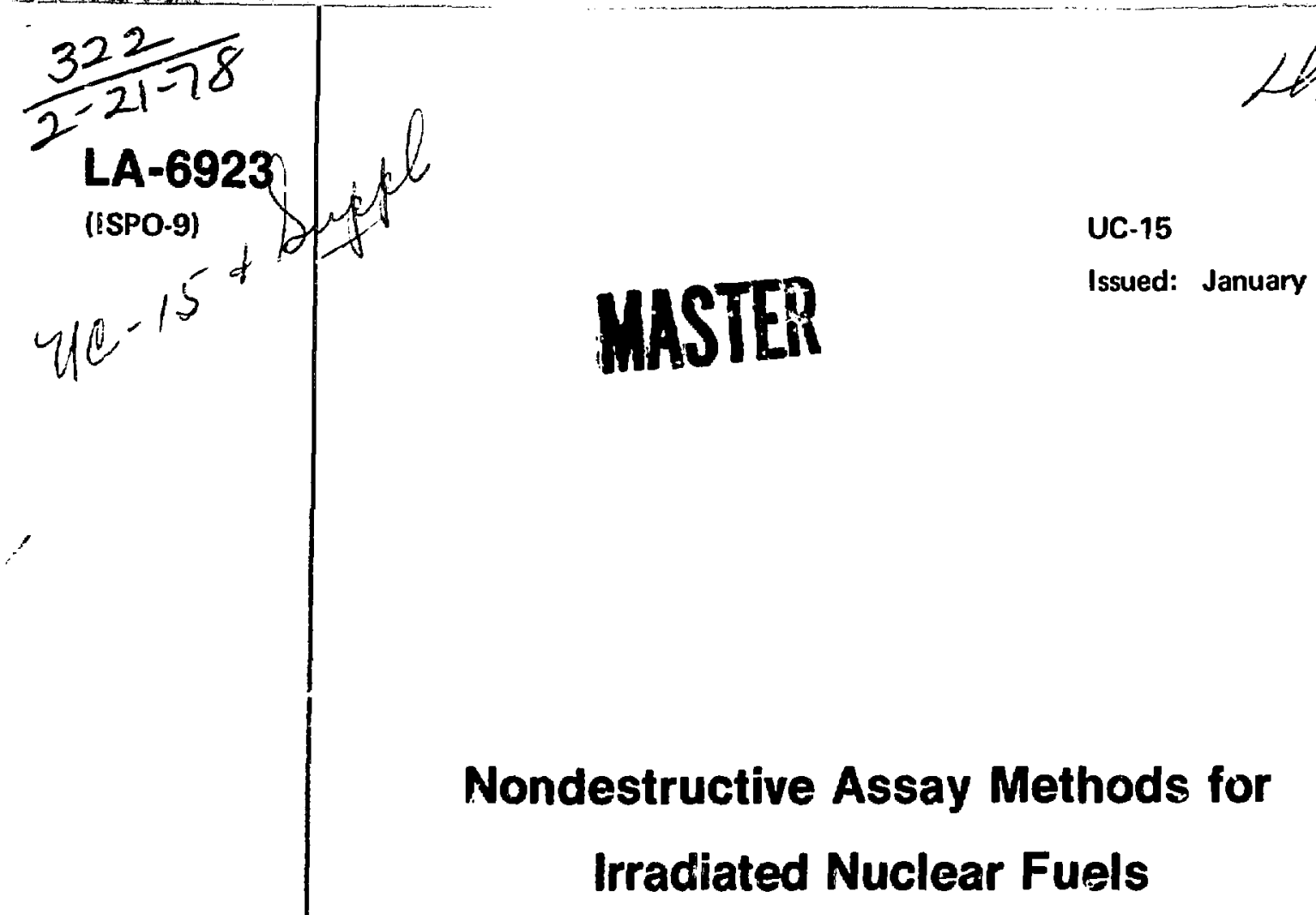

\title{
Nondestructive Assay Methods for Irradiated Nuclear Fuels
}

\author{
S. T. Hsue \\ T. W. Crane \\ W. L. Talbert, Jr. \\ John C. Lee*
}

"Consultant. University of Michigan, Ann Arbor, MI 48104.

asty 1 a a a

sciantifte laboratory

of the University of Californic

lOS ALAMOS, NEW MEXICO 87545

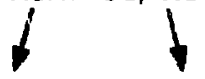

An Affirmative Action/Equal Opporlunity Employer
PROGRAM FOR

TECHNICAL ASSISTANCE

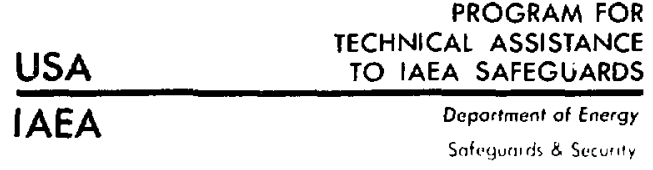




\begin{tabular}{|c|c|}
\hline CONTENTS & 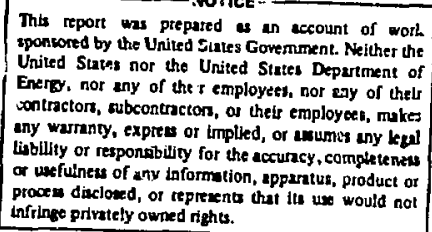 \\
\hline
\end{tabular}

ABSTRACT $\ldots \ldots \ldots \ldots \ldots \ldots \ldots \ldots \ldots \ldots \ldots \ldots \ldots \ldots \ldots$

I. INTRODUCTION $\ldots \ldots \ldots \ldots \ldots \ldots \ldots \ldots \ldots \ldots \ldots \ldots \ldots \ldots$

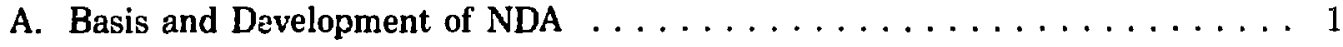

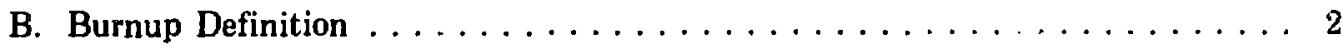

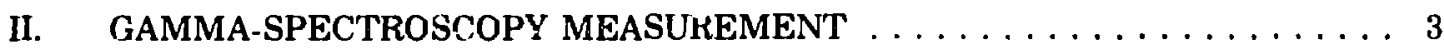

A. Choice of Fission Product $\ldots \ldots \ldots \ldots \ldots \ldots \ldots \ldots \ldots \ldots$

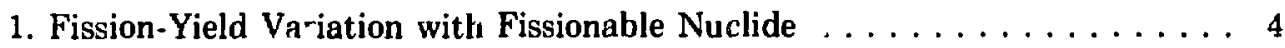

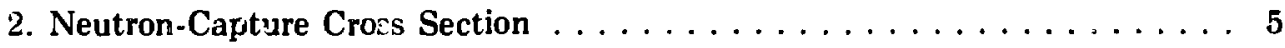

3. Half-Life Relative to Irradiation Period $\ldots \ldots \ldots \ldots \ldots \ldots \ldots$

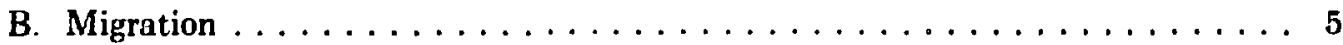

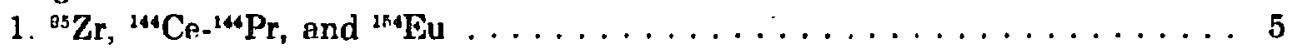

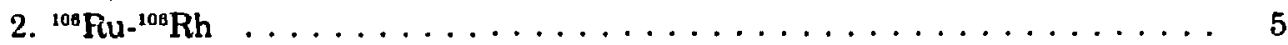

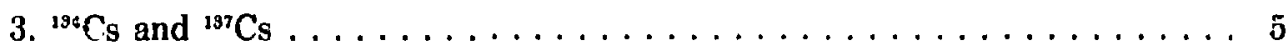

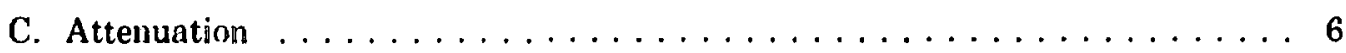

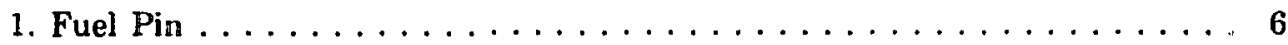

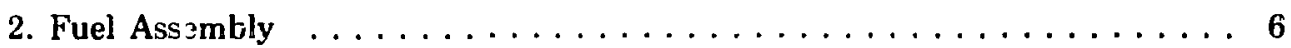

D. Absoiute Activity Measurement $\ldots \ldots \ldots \ldots \ldots \ldots \ldots \ldots \ldots \ldots$

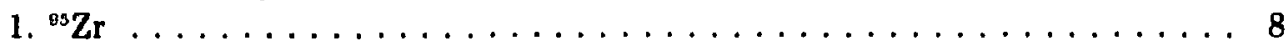

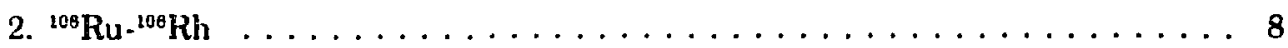

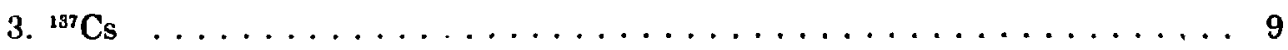

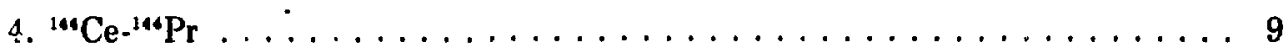

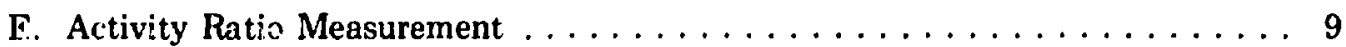

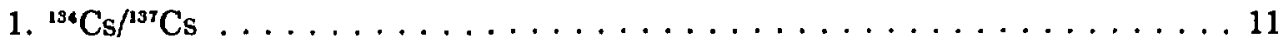

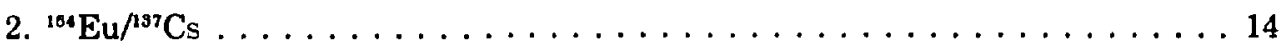

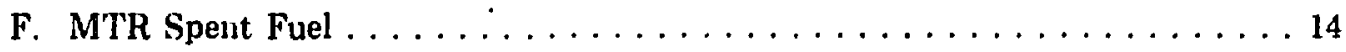

III. NEUTRON MEASUREMENTS $\ldots \ldots \ldots \ldots \ldots \ldots \ldots \ldots \ldots \ldots \ldots \ldots$

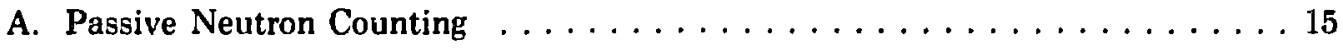

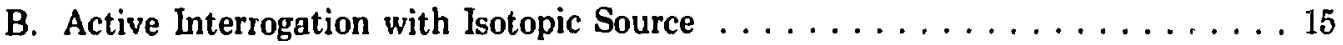

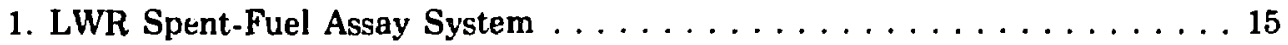

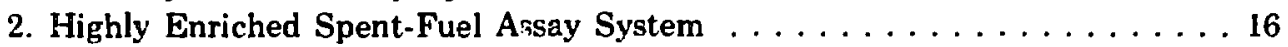

C. Active Interrogation with an Accelerator $\ldots \ldots \ldots \ldots \ldots \ldots \ldots \ldots$

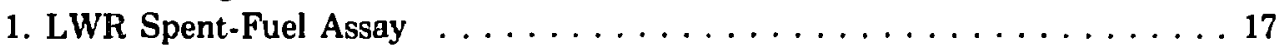

2. Highly Enriched Spent-Fuel Assay . . . . . . . . . . . . . 17

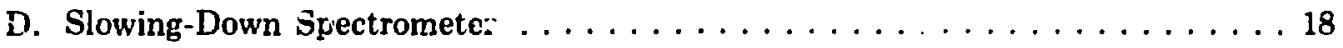

E. Neution Resonance Absorption $\ldots \ldots \ldots \ldots \ldots \ldots \ldots \ldots \ldots \ldots \ldots$

IV. OTHER MEASUREMENT TECHNIQUES $\ldots \ldots \ldots \ldots \ldots \ldots \ldots \ldots$

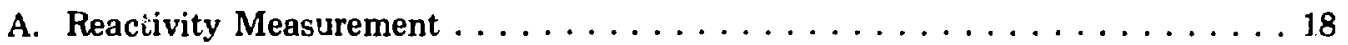

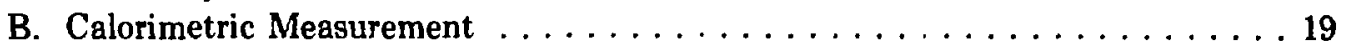


v. SUMMARY AND DISCUSSION $\ldots \ldots \ldots \ldots \ldots \ldots \ldots \ldots \ldots \ldots \ldots \ldots$

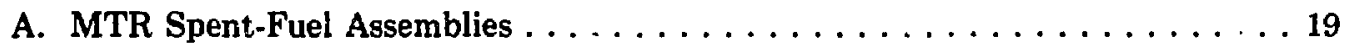

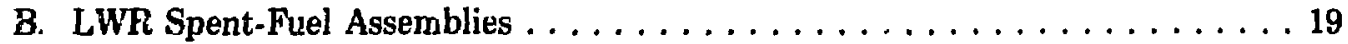

ACKNOWLEDGMENTS $\ldots \ldots \ldots \ldots \ldots \ldots \ldots \ldots \ldots \ldots \ldots \ldots \ldots \ldots \ldots \ldots \ldots$

APPENDIX: BURNUP PREDICTION CAPABILITY FOR PWR, BWR, AND CANDU REACTORS

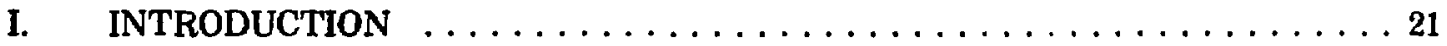

II. COMPARISON OF REACTOR TYPES $\ldots \ldots \ldots \ldots \ldots \ldots \ldots \ldots \ldots 22$

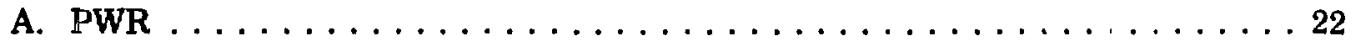

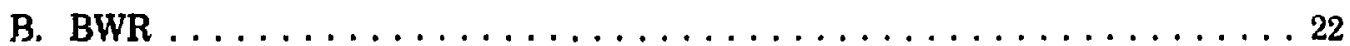

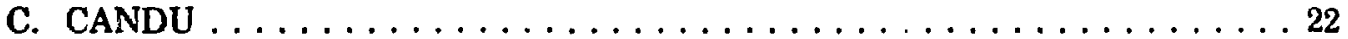

III. CALCULATIONAL METHODS FOR BURNUY DETERMINATION $\ldots \ldots \ldots 23$

IV. EXPERIMENTAL METHODS FOR BURNUP DETERMINATIONS $\ldots \ldots \ldots 24$

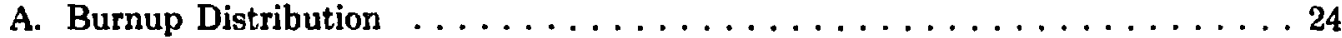

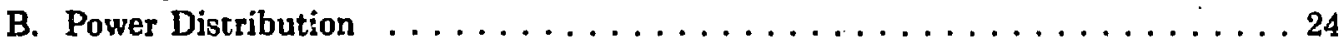

v. ACCURACY IN BURNUP PREDICTIONS $\ldots \ldots \ldots \ldots \ldots \ldots \ldots \ldots \ldots$

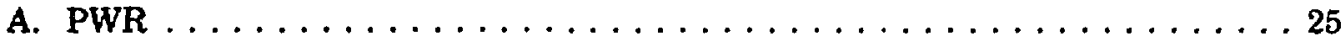

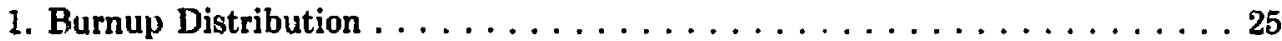

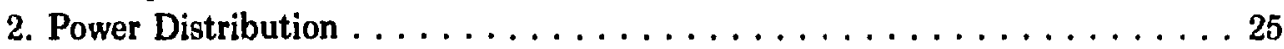

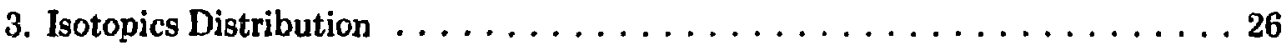

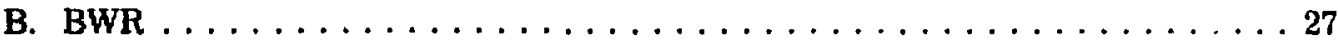

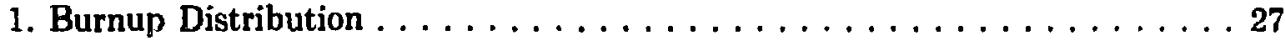

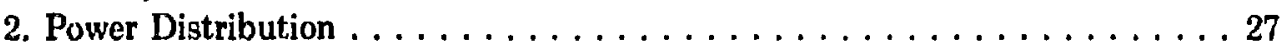

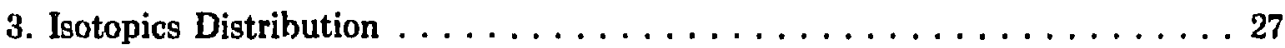

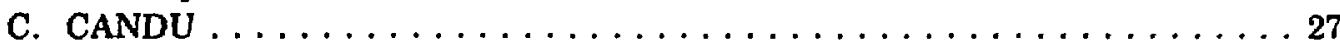

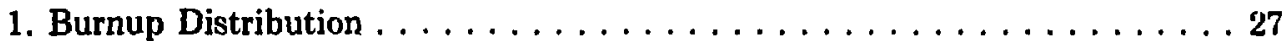

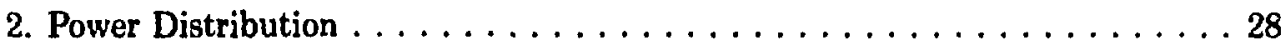

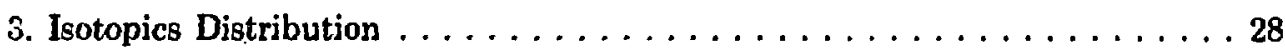

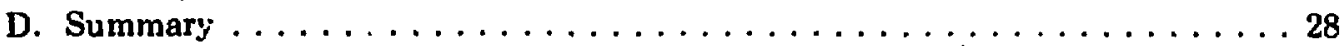

VI. CONCLUDING REMARKS $\ldots \ldots \ldots \ldots \ldots \ldots \ldots \ldots \ldots \ldots \ldots$

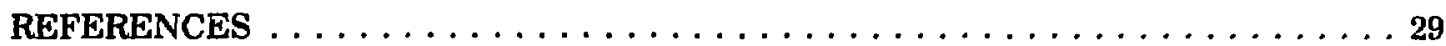




\section{FIGURES}

1. Diametral isotopic distributions of ${ }^{108} \mathrm{Rh},{ }^{137} \mathrm{Cs}$,

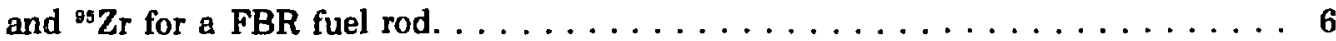

2. Differences in per cent of ${ }^{137} \mathrm{Cs}$ activity measured from a fuel rod with and without radial migration. . . . . . . . . . . . . 7

3. Typical absolute gamma activity measuring cquipment with the scanning mechanism. $\ldots \ldots \ldots \ldots \ldots \ldots \ldots \ldots \ldots$

4. Typical gamma activity ratio measuring equipment. $\ldots \ldots \ldots \ldots \ldots \ldots 11$

5. Error $(\Delta)$ in the intrinsic calibration method caused by a $20 \%$ nonuniform burnup. Point $A$ is the transmission through the assembly at $962-\mathrm{keV}$ gamma, interpolated from various ${ }^{194} \mathrm{Cs}$ gamma-ray peaks. Point $\mathrm{B}$ is transmission from actual ${ }^{137} \mathrm{Cs}$ activity distribution. . . . . . . . . . . . . . . . . . .

6. Neutrons per second from ${ }^{80 \mathrm{Pu}} \mathrm{Pu},{ }^{200} \mathrm{Pu},{ }^{202} \mathrm{Cm}$, and

${ }^{244} \mathrm{Cm}$ isotopes at a burnup of $26884 \mathrm{MWD} / \mathrm{MTU}$. The total number of neutrons includes contributions from the other uranium, plutonium, and anericium isotopes of the Trino reactor fuel. . . . . . . . . . . . . . . . . . . . . . .

7. Total number of neutrons per second vs burnup at discharge and after $2 \mathrm{yr}$ cooling for the Trino reactor fuel.

8. Conceptual design of an LWR fuel assembly assay system. $\ldots \ldots \ldots \ldots \ldots$

9. Irradiation region of the radium $(\gamma, \mathbf{n})$ beryllium assay system for measuring ${ }^{235} \mathrm{U}$ content in irradiated Rover fuel rod tubes. 


\section{TABLES}

1. RADIOACTTVE FISSIOIN ISOTOPES FOR BURNUP MONITORING $\ldots \ldots \ldots$

II. STANDARD ERRORS OF BURNUP OR PU/U RATIO FROM

NONDESTRUCTIVE MEASUREMENT OF ${ }^{137} \mathrm{Cs}$ ACTIVITY $\ldots \ldots \ldots \ldots \ldots$

III. STANDARD ERRORS OF BURNUP OR Pu/U RATIO FROM

NONDESTRUCTIVE MEASUREMENT OF ${ }^{184} \mathrm{Cs} /{ }^{387} \mathrm{Cs}$

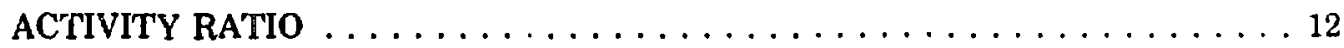

IV. SUMMARY OF NDA TECHNIQUES ON SPENT FUEL $\ldots \ldots \ldots \ldots \ldots 20$

A-I. FUEL BURNUP PREDICTION ACCURACY $\ldots \ldots \ldots \ldots \ldots \ldots \ldots \ldots$ 


\title{
NONDESTRUCTIVE ASSAY METHODS \\ FOR IRRADIATED NUCLEAR FUELS
}

\author{
by \\ S. T. Hsuc, T. W. Crane, \\ W. L. Talbert, Jr., and John C. Lee
}

\begin{abstract}
This report is a review of the status of nondestructive assay (NDA) methods used to determine burnup and fissile content of irradiated nuclear fuels.

The gamme-spectroscopy method measures gamma activities of certain fission products that are proportional to the burnup. Problems associated with this method are migration of the fission products and gamma-ray attenuation through the relatively dense fuel material. The attenuation correction is complicated by generally unknown activity distributions within the assemblies.

The neutron methods, which usually involve active interrogation and prompt or delayed signal counting, are designed to assay the fissile content of the spent-fuel elements. Systems to assay highly enriched spent-fuel assemblies have been tested extensively. Feasibility studies have been reported of systems to assay light-water reactor spent-fuel assemblies. The slowing-down spectrometer and neutron resonance absorption methods can distinguish between the uranium and plutonium fissile contents, but they are limited to the assay of individual rods.

We have summarized the status of NDA techniques for spent-fuel assay and present some subjects in need of further investigation. Aecuracy of the burnup calculations for power reactors is also reviewed.
\end{abstract}

\section{INTRODUCTION}

\section{A. Basis s ind Development of NDA}

Nondestructive assay (NDA) methods used to determine burnup and fissile content of irradiated nuclear fue s are needed to sefeguard against diversion of fissile materials to illegal weapon use. A capability for nondestructive assay of individual fuel assemblies is particularly important in view of the present trend of delay and cancellation in the construction of fuel reprocessing facilities. Because spent fueis are a major source of plutonium, measurement capability $b_{y}$ the International Atomic Energy Agency (IAEA) is essential for effective international safeguards. Such assay capability can provide fissile inventory on irradiated fuel, either stored or shipped, for reprocessing. NDA can improve reprocessing plant accountability informa. tion before fuel dissolution and thereby enhance 
operational efficiency and overall safeguards for the nuclear fuel cycle.

The inspection agency and the reprocessing plant have different viewpoints on acceptable assay systems. From the inspector's point of view, the preferred NDA method should use portable equipment for rapid and reasonably accurate assays. Fnr reprocessing plants, however, a method is wanted that approaches the accuracy obtainable with radiochemical or mass-spectrometric destructive analyses, and that can separate uranium and plutonium fissile content; equipment portability is less important.

In this review, ,e assume that the irradiated fuel assembly to be assayed can be isolated from other assemblies in storage. Assay in a storage pool without isolation capability is outside the scope of this review.

The last compreh hensive review on this subject was by Eidwardis ${ }^{t}$ in 1968 . Since then there has been substantial development of NDA methods and vast improvement in instrumentation. A review on gammaspectroscopy NDA techniques was reported by Dragnev ${ }^{2}$ in 1974. Our review, which includes passive and active neutron techniques and gammaspectrcscopy assay method, covers studies published through January 1977.

Gamma-spectroscopy measurements and associated difficulties, and activity migration and attenuation are discussed in Sec. II. The neucron measurements, both passive and active interrogation, are reviewed in Sec. III. The reactivity and calorimetric methods are discussed in Sec. IV. The summary and discussions are presented in Sec. $V$, and in the Appendix, present burnup calculation accuracies are reviewed.

\section{B. Burnup Definition}

Because the principal goal of assaying spent fuel is to determine burnup and/or fissile content, definition of burnup is needed. The two common definitions are:

(1) Burnup is the number of fissions per 100 heavy nuclides iniiially present in fuel.

(2) Bumup is the intrgrated energy released from the fission of heavy nuclicies initially present in fuel.
The first definition is used for dissolved irradiated fuel, and concentrations of a selected fissionproduct burnup monitor and the heavy nuclide atoms are determined.

The burnup computational relationship is then

$\mathrm{BU}(\%)=100 \frac{\mathrm{P} / \mathrm{Y}}{\mathrm{P} / \mathrm{Y}+\mathrm{H}}$,

in which

$$
\begin{aligned}
\mathrm{BU}(\%)= & \text { per cent fission, } \\
\mathrm{P}= & \text { atom concentration of fission-product } \\
& \text { burnup monitor, } \\
\mathrm{Y}= & \text { effective fractional fission-yield value, } \\
& \text { and } \\
\mathrm{H}= & \text { final atom concentration of heavy } \\
& \text { nuclides (mass } \geq 232) .
\end{aligned}
$$

The second definition is used mainly for power reactors, where burnup is expressed in MWD/MTU (megkwatt days per metric ton uranium initial). In NDA of spent fuel, this definition is used because heavy nuclides are not determined.

The burnup relationship is

Number of fission/MTU $=\frac{N}{Y}$.

$\mathrm{BU}(M W D / M T U)=1.8563 \times 10^{-24} \times \mathrm{E} \times \frac{\mathrm{N}}{\mathrm{Y}}$,

in which

$$
\begin{aligned}
\mathbf{N}= & \text { number of atoms of burnup monitor for- } \\
& \text { med during irradiation per metric ton of } \\
& \text { initial heavy metal, } \\
\mathrm{Y}= & \text { effective fractional fission-yield value, } \\
& \text { and } \\
\mathrm{E}= & \text { effective energy released per fiesion in } \\
& \mathrm{MeV} .
\end{aligned}
$$

The two burnup expressions are related by the conversion

$\mathrm{BU}(\mathrm{MWD} / \mathrm{MTU})=46.977 \times \mathrm{E} \times \mathrm{BU}(\%)$.

Both the effective fission yield and the energy released per fission depend on the relative fission contribution from plutoniun and uranium. 


$$
\mathrm{Y}=\frac{\sum_{\mathrm{f}}^{235} \mathrm{Y}^{235}+\sum_{\mathrm{f}}^{238} \mathrm{Y}^{238}+\sum_{\mathrm{f}}^{239} \mathrm{Y}^{239}+\sum_{\mathrm{f}}^{241} \mathrm{Y}^{241}}{\sum_{\mathrm{f}}^{235}+\sum_{\mathrm{f}}^{238}+\sum_{\mathrm{f}}^{239}+\sum_{\mathrm{f}}^{241}},
$$

and

$$
E=\frac{\sum_{\mathrm{f}}^{235} \mathrm{E}^{235}+\sum_{\mathrm{f}}^{238} \mathrm{E}^{238}+\sum_{\mathrm{f}}^{239} \mathrm{E}^{239}+\sum_{\mathrm{f}}^{241} \mathrm{E}^{241}}{\sum_{\mathrm{f}}^{235}+\sum_{\mathrm{f}}^{238}+\sum_{\mathrm{f}}^{239}+\sum_{\mathrm{f}}^{241}},
$$

in which

$$
\begin{aligned}
\sum_{\mathrm{I}}^{(1)}= & \text { time-averaged macroscopic fission cross } \\
& \text { section } \\
\text { of } \mathrm{I}= & { }^{236} \mathrm{U},{ }^{239} \mathrm{U},{ }^{239} \mathrm{Pu} \text {, and }{ }^{241} \mathrm{Pu}, \\
\mathrm{Y}^{(1)}= & \text { fission yield of isotope } \mathrm{I} \text {, and } \\
\mathrm{E}^{(1)}= & \text { energy released per fission in } \mathrm{MeV} \text { of } \\
& \text { isotope } \mathrm{I} .
\end{aligned}
$$

Assuming an effective energy release of $202 \mathrm{MeV}$ per fission, a burnup of $1 \%$ cciresponds to a burnup of $9489 \mathrm{NWD} / \mathrm{MTU}$.

\section{GAMMA-SPECTROSCOPY NEASUREMENT}

Gamma spectrosinpy for determination of burnup of spent fuel has been investigated for a long time. 'The two NDA methods of gamma-ray assay are the absolute gamma acîivity measurement and the activity ratio measurement. The latter method was developed during the last several years and is still under intense investigation. Both methods measure que (ICT). General problems pertaining to all gamma burnup measurements and particular difficulties pertaining to each gamma assay method are discussed later in this section.

\section{A. Choice of Fission Product}

A radioactive fission-product burnup monitor should have

- near equal fission yields for the major fissioning nuclides in the fuel,

- low neutron-capture cross sections (including capture by precursors),

- long half-life relative to irradiation period,

- low migration (including precursors) in the fuel, and

- easily resolvable gamma-ray spectra with highenergy gamma rays to minimize attenuation.

The radioactive fission products that satisfy most of these criteria are summarized in Table I. As shown, the ${ }^{88} \mathrm{Zr}$, ${ }^{108} \mathrm{Ru},{ }^{197} \mathrm{Cs}$, and ${ }^{144} \mathrm{Ce}$ isotopes arise directly from the beta decay of precursor fission products, e.g.,

$$
{ }^{137} \mathrm{I} \underset{24 \mathrm{~s}}{\longrightarrow}{ }^{137} \mathrm{Xe} \underset{4.2 \mathrm{~m}}{\longrightarrow}{ }^{137} \mathrm{Cs} \underset{30.0 \mathrm{y}}{\longrightarrow}{ }^{137} \mathrm{Ba}^{\mathrm{m}} \underset{2.6 \mathrm{~m}}{\longrightarrow}{ }^{137} \mathrm{Ba}
$$

the gamma activity of some selected fission products. The methods do not yield the îssile content directly, but it may be inferred from burnup calculation or from the isotopic correlation techni-
Tine ${ }^{134} \mathrm{Cs}$ and ${ }^{154} \mathrm{Eu}$ isotopes are shielded nuclides-not direct products of fission. They are formed by $(\mathrm{n}, \gamma)$ reactions on ${ }^{193} \mathrm{C}$ s and ${ }^{163} \mathrm{Eu}$, respectively, which are produced in fission 


$$
{ }^{133} \mathrm{I} \underset{21 \mathrm{~h}}{\longrightarrow}{ }^{133} \mathrm{Xe} \underset{5.27 \mathrm{~d}}{\longrightarrow}{ }^{133} \mathrm{Cs}(\mathrm{n}, \gamma)^{134} \mathrm{Cs} \underset{2.1 \mathrm{y}}{\longrightarrow}{ }^{134} \mathrm{Ba}
$$

and

$$
{ }^{153} \mathrm{Sm} \underset{46.7 \mathrm{~h}}{\longrightarrow}{ }^{153} \mathrm{Eu}(\mathrm{n}, \gamma){ }^{154} \mathrm{Eu} \underset{8.6 \mathrm{y}}{\longrightarrow}{ }^{154} \mathrm{Gd}
$$

These two nuclides, which are used in the activity ratio method to determine burnup, are discussed later in this section.
1. Fission-Yield Variation with Fissionable Nuclide. For effective fission-yield value to be constant with burnup level, the fission-product monitor

\section{TABLE I}

\begin{tabular}{|c|c|c|c|c|c|}
\hline \multirow[b]{2}{*}{ Isotope } & \multirow[b]{2}{*}{ Half-Life } & \multicolumn{2}{|c|}{ Thermal Fission Yield $(\%)^{b}$} & \multicolumn{2}{|c|}{ Principal Gamma Rays ${ }^{\mathrm{c}}$} \\
\hline & & ${ }^{234} \mathrm{U}$ & ${ }^{2 * 9} \mathbf{P u}$ & Energy (keV) & Branching (\%) \\
\hline${ }^{\circ} \mathrm{Zr}$ & $65.5 \mathrm{~d}$ & 6.50 & 5.01 & $\begin{array}{l}724.18 \\
756.72\end{array}$ & $\begin{array}{l}44.4 \\
54.6\end{array}$ \\
\hline${ }^{108} \mathrm{Ru}-{ }^{100} \mathrm{Rh}$ & 369. d & 0.39 & 4.48 & $\begin{array}{r}511.85 \\
621.87 \\
1050.39 \\
1128.07\end{array}$ & $\begin{array}{r}20.6 \\
9.8 \\
1.5 \\
0.4\end{array}$ \\
\hline${ }^{184} \mathrm{Cs}_{3}$ & 2.06 & $\begin{array}{l}6.75 \\
\quad \text { (Yield of }{ }^{100} \mathrm{Cs} \text { ) }\end{array}$ & 7.42 & $\begin{array}{r}569.35 \\
604.73 \\
795.84 \\
801.94 \\
1365.00\end{array}$ & $\begin{array}{r}15.4 \\
97.6 \\
85.4 \\
8.7 \\
3.3\end{array}$ \\
\hline${ }^{197} \mathrm{Cs}$ & $30.12 \mathrm{y}$ & 6.26 & 6.65 & 661.64 & 85.0 \\
\hline${ }^{140} \mathrm{Ce}-{ }^{114} \mathrm{Pr}$ & $284.4 \mathrm{~d}$ & 5.39 & 3.80 & $\begin{array}{r}696.49 \\
1489.15 \\
2185.70\end{array}$ & $\begin{array}{l}1.51 \\
0.29 \\
0.74\end{array}$ \\
\hline${ }^{108} 1 \mathrm{Eu}$ & $8.6 \mathrm{y}$ & $\begin{array}{l}0.164 \\
\quad\left(\text { Yield of }{ }^{180} \mathrm{Eu}\right)\end{array}$ & 0.285 & $\begin{array}{r}591.78 \\
723.31 \\
873.25 \\
996.37 \\
1274.50\end{array}$ & $\begin{array}{r}4.9 \\
19.7 \\
11.7 \\
10.1 \\
34.7\end{array}$ \\
\hline
\end{tabular}

\section{RADIOACTIVE FISSION ISOTOPES FOR BURNUP MONITORING}

- Half-lives of the isotopes were obtaired from ENDF/B-IV Fission-Product Files as reported in Lo3 Alamos Scientific Laboratory report LA-6116-MS (1975).

'Thermal fission yields were obtained for the Atomic Energy of Canada Limited report AECL4704 (February 1974).

'Gamma-ray energies and branchings were obtained from Nuclear Datu Sheets, Oak Ridge National Latoratory. 
should have equal fission yields for the major fissioning nuclides in the fuel. If the fission yields are substantially different, the effective fission yield will depend somewhat on the reactor's operating history.

\section{Neutron-Capture Cross Section. The} neutron-capture cross-section value must be low enough that the ratio of produced fission-produst atoms to fission is virtually independent of burnup.

3. Half-Life Relative to Irradiation Period. If the irradiation time is less than the half-life of the fission product, the number of fission-product monitor nuclides formed is approximately proportional to the number of fissions [Eq. (2)]. However, if the irradiation time exceeds the half-life, this relation will not be valid and an irradiation or power history correction will be necessary.

\section{B. Migration}

If the fission-product precursors are volatile, they may undergo migration relative to their formation positions in uranium and plutonium fission. Racial migration of precursors generally is much more drastic than axial migration because the radial temperature differential is much larger than the axial for oxide fuel. The following discussions include some postirradiation results from fast breeder reacior (FBR) fuels. We include FBR results because (1) more migration studies have been reported for FBR fuel than for light-water reactor (LWR) fuel, and (2) FBR fuels usually are operated with higher temperatures and can serve as limiting cases for LWR fuels.

1. ${ }^{83} \mathrm{Zr}$, ${ }^{14} \mathrm{Ce}-{ }^{144} \mathrm{Pr}$, and ${ }^{164} \mathrm{Eu}$. Forsyth et al. ${ }^{3}$ measured the migration of ${ }^{\circ 5} \mathrm{Zr}$ and ${ }^{14} \mathrm{Ce}$ in fuel rods irradiated for $3 \mathrm{yr}$ and with fuel centerline temperatures between 1750 and $2050^{\circ} \mathrm{C}$. Phillips et al. ${ }^{4,5}$ also studied the migration of ${ }^{95} \mathrm{Zr}$ and ${ }^{144} \mathrm{Ce}$ in $\mathrm{FBR}$ fuel rods. Rein ${ }^{6}$ studied the migration of rare earth elements in mixed-oxide FBR fuels. These studies show that apparently ${ }^{80} \mathrm{Zr},{ }^{144} \mathrm{Ce}$, and ${ }^{164} \mathrm{Eu}$ do not migrate significantly, either radially or axially relative to the heavy metal.
2. ${ }^{108} \mathrm{Ru}-{ }^{100} \mathrm{Rh}$. However, ${ }^{100} \mathrm{Ru}-{ }^{106} \mathrm{Rh}$ is volatile, and both radial and axial migrations have boen observed..$^{34}$ In the radial direction, the ${ }^{106} \mathrm{Rh}$ isotope tends to concentrate around the centarline of the fuel pellet; peripheral-to-center concentration of 1:20 has been observed."

3. ${ }^{194} \mathrm{Cs}$ and ${ }^{197} \mathrm{Cs}$. The ${ }^{197} \mathrm{Cs}$ migration has been detected in LWR fuel, ${ }^{3}$ in Canadian Deuterium Uranium (CANDU) fuel, ${ }^{7,8}$ and in FBR fuel. ${ }^{4,6,8}$ The ${ }^{134} \mathrm{Cs}$ migration has been studied mainly with FBR fuel. ${ }^{4,5,8}$

The ${ }^{134} \mathrm{Cs}$ and ${ }^{137} \mathrm{Cs}$ isotopes tend to migrate toward the cooler regions of the fuel section. In the radial direction, both isotopes migrate toward the ciadding; in the axial direction, they tind to concentrate in interpellet gaps. In their study of FBR fuels, Philips et al."r found differences in the relative concentrations of ${ }^{134} \mathrm{Cs}$ and ${ }^{197} \mathrm{Cs}$ as a function of axial positicns. The authors attributed these differences to ${ }^{197} \mathrm{Cs}$ migration mainly as the metal, and final ${ }^{134} \mathrm{Cs}$ distribution is the result of migration of either the ${ }^{193} \mathrm{I}$ or ${ }^{193} \mathrm{Xe}$ precursor. The amount of migration seems to dipend on temperature, oxysen-to-metal ratio, and fiel density. The higher the oxygen-tometal ratio, the less migration tends to occur. In their fission-product migration studies on LWR fuels, Forsyth e al. ${ }^{3}$ found no ${ }^{197} \mathrm{Cs}$ migration at a fuel centerline temperature $<1200^{\circ} \mathrm{C}$; however, there was migration at a fuel ctnterline temperature between 1750 and $2050^{\circ} \mathrm{C}$. The temperature threshold of the migration effect of ${ }^{187} \mathrm{Cs}$ has not been resolved. Dragnev ${ }^{2}$ proposed a threshold temperature of $1500^{\circ} \mathrm{C}$; Hiller ${ }^{10}$ suggested $2000^{\circ} \mathrm{C}$. Published data on the degree of ${ }^{137} \mathrm{Cs}$ migration vary widely. Peripheral-to-center concentrations of 10:1 have been reported by Forsyth et al., and up to 1000:1 by Bates' for $\mathrm{UO}_{2}$ thermal reactor fuels. Figure 1 shows typical diametral isotopic distributions ${ }^{4}$ of ${ }^{137} \mathrm{Cs}$, ${ }^{108} \mathrm{Rh}$, and ${ }^{98} \mathrm{Zr}$, in which the ${ }^{83} \mathrm{Zr}$ distribution represents no migration.

The ${ }^{18} \mathrm{Cs}$ migration for LWR fuel has not been studied and is thus speculative. The ${ }^{194} \mathrm{Cs}$ and ${ }^{137} \mathrm{Cs}$ migrations may be different because the nuclides responsible for the migration are different. 


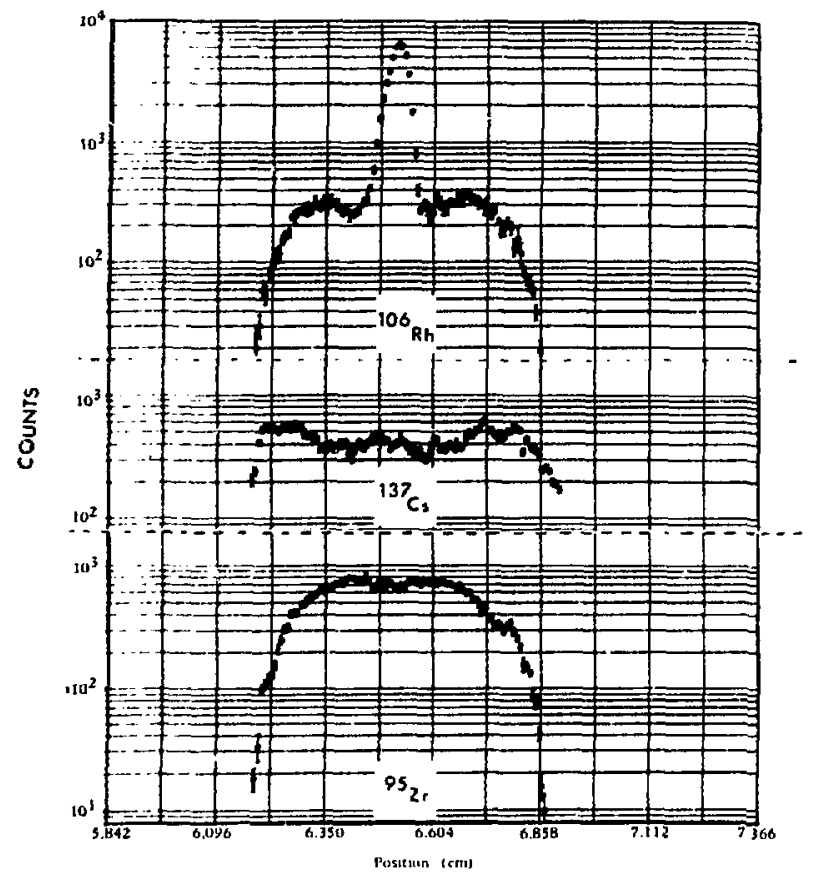

Fig. 1.

Diametral isotopic distributions of ${ }^{106} \mathrm{Rh},{ }^{137} \mathrm{Cs}$, and ${ }^{8 B} Z$ r for a FBR fuel rod.

\section{Attenuation}

1. Fuel Pin. Gamma-ray intensities are attenuated as they emerge from the fuel pin. The attenuation depends on gamma-ray energy and on activity distribution within the pins. To minimize the attenuation effect, only relatively high-energy fission-product gamma rays $(\mathrm{E}>500 \mathrm{keV})$ are used in the spent-fuel gamma assay. On the other hand, the oxide fuel density is comparatively high (10.9 $\mathrm{g} / \mathrm{cm}^{3}$ ); for the $661-\mathrm{keV}$ gamma ray of ${ }^{187} \mathrm{Cs}$, the selfattenuation factor within the 1-cm-diam fuel pin is $\sim 0.63$, or $\sim 37 \%$ of the gamma intensity is attenuated within the pin, assuming a uniform activity distribution.

The attenuation correction is complicated by fracturing and/or formation of center voids in the fuel rods and by the activity distribution within the rods. It is difficult to predict void formation or fuel fracture; the processes depend on the fuel temperature and irradiation history, among other factors. The activity distribution within the rod depends on migration and burnup distribution throughout the irradiasion.
Migration of the various radioactive fissionproduct burnup monitors was discussed in the previous section. The activities of ${ }^{8} \mathrm{Zr}$, ${ }^{1 "} \mathrm{Ce}$, and ${ }^{15} \mathrm{Eu}$ do not migrate relative to the heavy metals, whereas those of ${ }^{108} \mathrm{Ru}-{ }^{108} \mathrm{Rh},{ }^{184} \mathrm{Cs}$, and ${ }^{137} \mathrm{Cs}$ have been observed to migrate.

To estimate the activity distribution effect on attenuation correction, assume that ${ }^{137} \mathrm{Cs}$ migrates radially toward the fuel periphery to produce a concentration profile described empirically by

$A(r)=\mathrm{Ke}^{-\mathbf{B ( R - r )}}$,

where

$$
\begin{aligned}
A(r) & =\text { activity per unit length at } r \\
K & =\text { arbitrary constant, } \\
R & =\text { fuel pin radius, } \\
B & =(1 / 2) \text { arcosh }\left(A_{2} / A_{1}\right) \\
A_{2} & =\text { peripheral activity per unit length, and } \\
A_{1} & =\text { center activity per unit length. }
\end{aligned}
$$

The $662-\mathrm{keV}$ gamma flux values received by a detector from a fuel rod with this activity distribution were calculated by numerical integration and compared with those from a fuel rod containing the same total quantity of the ${ }^{197} \mathrm{Cs}$ activity but homogeneously distributed. The calculation was performed for the collimated case (collimator width $<R$ ) and uncollimated case (collimator width 2R). Figure 2 shows a series of curves for fuel rod densities of $10.5 \mathrm{~g} / \mathrm{cm}^{3}$ (96\% of $\mathrm{UO}_{2}$ density) and diameters of $0.7,1.0,1.3$, and $1.6 \mathrm{~cm}$. The degree of activity distribution varies from $A_{2} / A_{1}=1$ (uniform distribution) to $A_{2} / A_{1}=100$. The counting rate from the nonuniformly distributed activity is consistently higher. The error from assuming a uniform distribution depends on fuel pin radius and activity distribution within the pin. Radial activity distribution within a rod can be determined by horizontal scanning with narrow collimation in a hot-cell environment, but it will be difficult to determine in field inspection.

2. Fuel Assembly. In measuring spent fuels, there is a distinct advantage in assaying a whole assembly instead of individual fuel pins because the assembly does not have to be taken apart. However, 


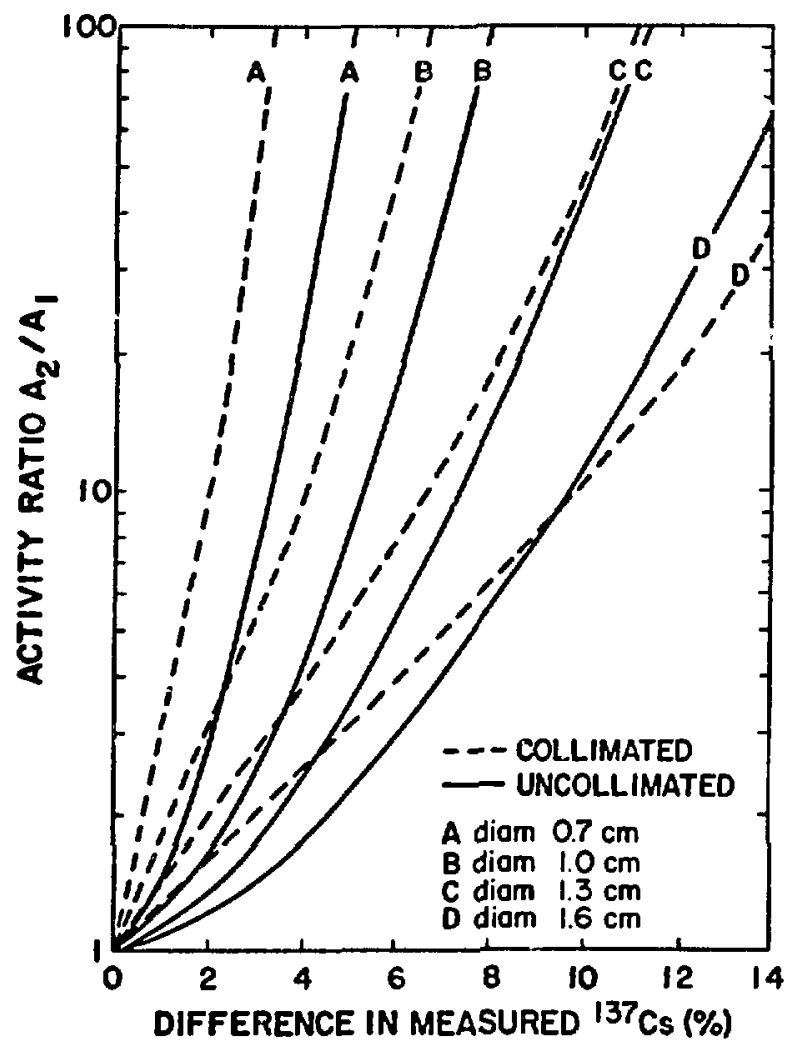

Fig. 2.

Differences in per cent of ${ }^{187} \mathrm{Cs}$ activity measured from a fuel rod with and without radial migration.

the advantage must be weighed against complications introduced by attenuation through the whole assembly and nonuniform burnup within the assembly. In whole, square-assembly assay, corner measurements are preferable to side measurements. Experience has shown that for side measurements on fuel assemblies, a $30 \%$ variation in the $1.60-\mathrm{MeV}$ ${ }^{10} \mathrm{La}$ gamma activity was produced by a $10^{\circ}$ angular variation of the collimator-detector axis, but the same angular deviation caused $\sim 1.5 \%$ variation in corner measurements. ${ }^{12}$

Because of strong attenuation in the fuel rods, only the rods closest to the corner in front of the collimator contribute significantly to the measured gamma activity. The gamma-ray transmission through a boiling water reactor (BWR) fuel pin (1cm o.d.) is $\sim 0.29$ at $661 \mathrm{keV}$. For an 8 -by-8 BWR fuel assembly submerged ir water, only $\sim 1 \%$ of the total ${ }^{197} \mathrm{Cs}$ activity of the four central rods is measured. There is a "black-out zone" in the center of the assembly where gamma activity cannot be assayed. The same situation prevails for a CANDU bundle and is even more drastic for a pressurized water reactor (PWR) fuel assembly.

A further complication in whole-assembly assay is nonuniform distribution of the flux during irradiation. In a BWR assembly, the rods at the edge of the assembly sometimes experience a higher burnup because they are near the water gap. In a CANDU fuel bundle, similar burnup variations among fuel pins have been found. ${ }^{8}$

It is difficult to measure activity distribution within the assembly. If detailed reactor operation conditions are known, the activity distribution of fission products can be calculated by some burnup computer codes. From the rod-to-rod distribution of the fission-product activity, the assembly attenuation factor can be calculated. Therefore, the accuracy of the attenuation calculation depends critically on the accuracy of the burnup calculation, and is probably the most uncertain factor in the whole-assembly assay.

\section{Absolute Activity Measurement}

When the number $\mathrm{N}$ of burnup monitor atoms formed during irradiation is determined, the burnup can be calculated by Fq. (3). N is related to the gamma-ray intensities by

$N=\frac{x_{i}}{k_{i} \epsilon_{i} S_{i}} \frac{e^{\lambda T} c}{\lambda}$,

in which

$\mathrm{X}_{1}=$ number in the ith gamma-ray peak observed per unit time,

$k_{\mathfrak{l}}=$ number of the ith gamma ray per disintegration,

$\epsilon_{1}=$ absolute detector efficiency at the energy of the gamma-ray peak,

$S_{1}=$ the effective attenuation at the energy of the gamma-ray peak,

$\lambda=$ decay constzitt, and

$\mathrm{T}_{\mathrm{c}}=$ cooling time. 
In Eq. (11), the $k_{1}$ and $\lambda$ depend on the status of the nuclear data; and for these radioactive fissionproduct monitors, they are generally known to $\sim 1$ to $2 \%$. The $X_{1}$ can be measured to $1 \%$ or better. The attenuation factor $S_{1}$ may be determined fairly accurately for a single rod if diametral rod scan is performed; the uncertainty in $S_{1}$ is considerably larger for a whole assembiy. The most crucial and difficult factor to determine is the absolute detector efficiency $\epsilon_{1}$, which depends on the measurement geometry, the collimator, and the intrinsic efficiency of the detector. The absolute efficiency may be determined by a calibration source of known total activity. The geometries for assay and efficiency calibration must be identical.

In a well-controlled hot-cell environment, the absolute activity measurement can be fairly accurate in a burnup determination. The accuracy, advantages, and disadvantages of each fission-product monitor are discussed below. Accuracy can be achieved only under well-controlled geometry, which normally cannot be achieved in field inspection. The absolute activity method is probably limited to riprocessing plants. A typical experimental arrangement is shown in Fig. 3.

1. ${ }^{98} \mathrm{Zr}$. The fission yield of ${ }^{93} \mathrm{Zr}$ is relatively constant for ${ }^{298} \mathrm{U}$ and ${ }^{239} \mathrm{Pu}$ fission. Also the neutron absorption cross section is low and the activity does not seem to migrate. However, its relatively short half-life ( 65 days) limits its use as a burnup monitor to cases of not excessively long irradiation and cooling times.

Zirconium-95 $\left(\mathrm{T}_{1 / 2}=65.5\right.$ days $)$ decays to ${ }^{95} \mathrm{Nb}$ $\left(\mathrm{T}_{1 / 2}=35.15\right.$ days) and the two nuclides are in secular equilibrium if the production rate of ${ }^{\circ 5} \mathrm{Zr}$ is constant. The ratio of ${ }^{\circ 8} \mathrm{Zr}$ to ${ }^{\circ 8} \mathrm{Nb}$ is a constant during irradiation, but it drops to a different constant after a long cooling time. For a cooling time $<300$ days, the ratio can be used to determine the cooling time, ${ }^{2,19,14}$ and accuracies within $7 \%$ have been achieved. ${ }^{10}$

2. ${ }^{106} \mathbf{R u}-{ }^{100} \mathrm{Rh}$. Although the low neutron absorption cross section and the 1-yr half-life of ${ }^{100} \mathrm{Ru}$ make it a more suitable candidate as a burnup monitor, it has been known to migrate. ${ }^{8,4}$ The thermal neutron fission yield from ${ }^{239} \mathrm{Pu}$ is $\sim 11$ times that from ${ }^{230} \mathrm{U}$.
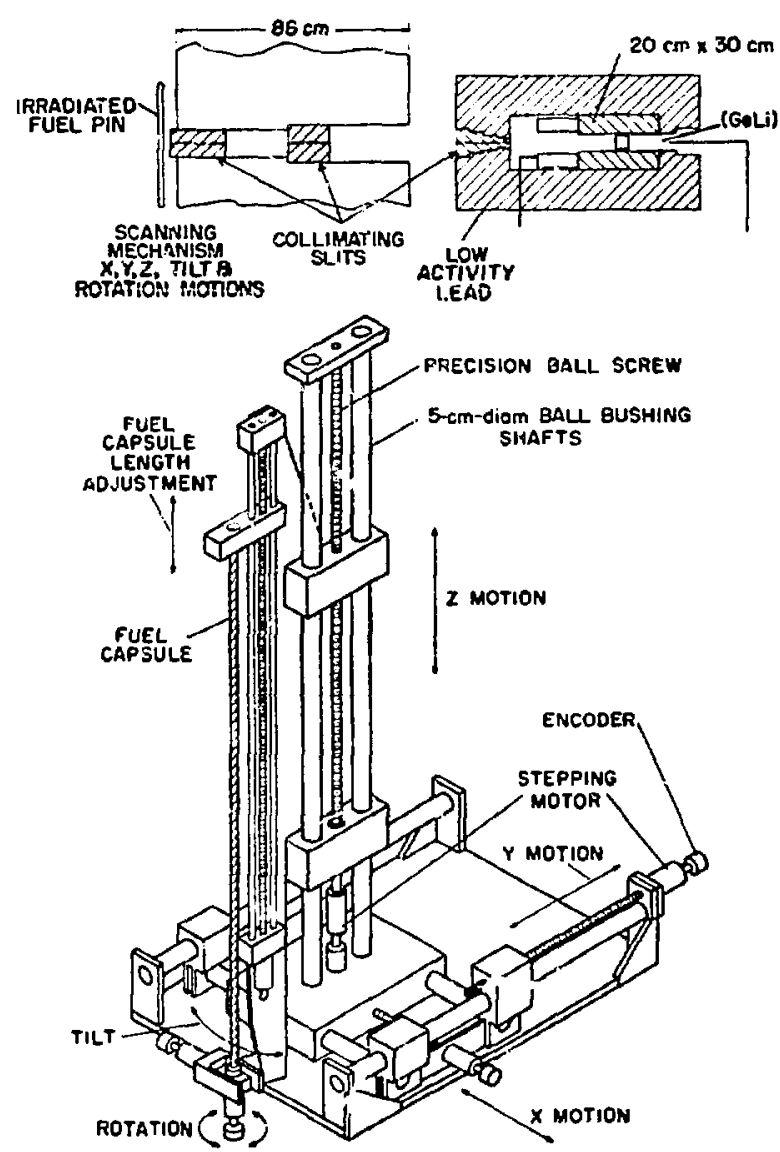

SCANNING MEChaNISM

Fig. 3.

Typical absolute gamma activity measuring equipment with the scanning mechanism.

Forsyth and Blackadder ${ }^{10}$ explored this drastic difference in fission yields to determine relative fission everits in ${ }^{295} \mathrm{U}$ and ${ }^{280} \mathrm{Pu}$. Agreement was obtained between experimental results and calculation, but careful irradiation history and decay correction were necessary to deduce the percentage of ${ }^{280} \mathrm{Pu}$ fission. For spent fuels that have been irradiated for a relatively long time (e.g., $3 \mathrm{yr}$ ), the uncertainty caused by irradiation history and decay corrections can be substantial. Previous studies also showed a substantial deviation between nondestructive and destructive determinations of the amount of ${ }^{100} \mathrm{Ru}$ ${ }^{106} \mathrm{Rh}$ in Trino reactor fuels ${ }^{17}(7.7 \%)$ and Dodewaard reactor fuels ${ }^{18}(14.9 \%)$. 
3. ${ }^{137}$ Cs. Cesium-137 is often considered the most suitable fission product for burnup measurements because (1) it has a relatively !ong half-life, (2) its neutron absorntion cross sections (and those of its precursors) are negligible, and (3) it has approzimately the same yields for both ${ }^{295} \mathrm{U}$ and ${ }^{290} \mathrm{Pu}$. The 30-yr half-life of ${ }^{197} \mathrm{Cs}$ makes the power history correction unnecessaly.

The major drawback of ${ }^{137} \mathrm{Cs}$ as a burnup monitor is that it migrates at high temperature and at low oxygen-to-metal ratio. Axial cesium migration can be checked by comparing ${ }^{197} \mathrm{Cs}$ with nonmigrating isctopes, for example, zirconium or praseodymium. The radial cesium migration introduces uncertainty in the attenuation correction. Also, in case of clad failure, ${ }^{137} \mathrm{Cs}$ cannot be used as a burnup monitor.

The results of several studies on the use of ${ }^{137} \mathrm{Cs}$ as a burnup monitor of spent fuels either in pellet or total assembly form are summarized in Table II. Burnup is determined by mass-spectroscopy measurements unless otherwise specified. Table II shows that with fuel rods, NDA of ${ }^{137} \mathrm{Cs}$ activity can determine burnup to an accuracy of 1 to $4 \%$ within a wide burnup range. When the whole assembly or bundle is assayed, the ${ }^{139} \mathrm{Cs}$ activity can determine burnup from 2 to $6 \%$. Because the Trino, Garigliano, and Bohunice reactors have been studied in. tensively, ${ }^{197} \mathrm{Cs}$ activity distributions within their assemblies or bundles (and therefore the attenuation factors) can be calculated accurately. The uncertainties of the whole-assembly assay for other reactor fuels depend largely on the uncertainties of the attenuation calculation. These uncertainties may be substantially larger than $6 \%$. In the assembly assays, measurements were performed at four corner: if the assembly and at eight or nine levels. The ${ }^{137} \mathrm{Cs}$ activities at all the measuring points were totaled to obtain an integral value for the fuel assembly.

4. ${ }^{14} \mathrm{Ce}-{ }^{144} \mathrm{Pr}$. The ${ }^{10} \mathrm{Ce}-{ }^{144} \mathrm{Pr}$ activity has a distinct advantage because it and its precursors do not migrate relative to the heavy metals. In addition, ${ }^{14} \mathrm{Pr}$ emits a $2.18-\mathrm{MeV}$ gamma radiation. The relatively high energy of this gamma radiation makes an accurate attenuation factor calculation less important. Nondestructive determinations of the amount of ${ }^{14} \mathrm{Ce}-{ }^{14} \mathrm{Pr}$, therefore, are generally quite accurate compared with destructive analyses (within $1.7 \%$ in Trino fuel pellets ${ }^{27}$ ).

These advantages must be weighed against its relatively short half-life of 284 days, and the somewhat differen: fission yields of ${ }^{236} \mathrm{U}$ and ${ }^{238} \mathrm{Pu}$ (Table I). These two drawbacks require a careful power history correction. In their study of ${ }^{104} \mathrm{Ce}-{ }^{14} \mathrm{Pr}$ as a fission monitor for CANDU reactor fuels, Chen et al. ${ }^{2 \triangleleft}$ found that the overall uncertainty in burnup determination can be as high as +30 to $-20 \%$, relative to calculated values for a 500-day irradiation period. The uncertainty decreases ( \pm 12 to $15 \%$ ) for a shorter irradiation period ( $\sim 300$ days).

\section{E. Activity Ratio Measurement}

Activity ratios have been suggested ${ }^{18,25}$ for use as burnup monitors. Several experiments since 1971 have explored this possibility and developrnent is continuing. If we assume that the flux is cunstant during irradiation, the activity from a direct fission product $\mathrm{N}_{\mathrm{D}}$ formed (such as ${ }^{197} \mathrm{Cs}$ ), and that from neutron capture of fission products $N_{1}$ (such as ${ }^{134} \mathrm{Cs}$ ) are respectively proportional to [see Eqs. (7) and (8)]

$N_{D} \propto \Sigma_{p} \cdot(\phi T)$ and

$\left.\mathrm{N}_{\mathrm{l}} \alpha \Sigma_{\ell} \cdot \sigma(\mathrm{n}, \gamma) \cdot \dot{\phi} \mathrm{T}\right)^{2}$

in which

$$
\begin{aligned}
\phi= & \text { spectrum and time-averaged neutron } \\
& \text { flux, } \\
\Sigma_{\mathrm{p}}= & \text { spectrum and time-averaged fission } \\
& \text { cross section, } \\
\sigma(\mathrm{n}, \gamma)= & \text { spectrum and time-averaged neutron- } \\
& \text { capture cross section of the fission } \\
& \text { product, } \\
& \text { and } \\
\tau= & \text { irradiation time. }
\end{aligned}
$$

Equations (12) and (13) show that the $N_{1} / N_{D}$ ratio is alsc proportional to $(\phi T)$ and, in principle, can be used as a burnup monitor. The activity ratios that have been explored up to now are ${ }^{194} \mathrm{Cs} /{ }^{137} \mathrm{Cs}$ and ${ }^{154} \mathrm{Eu} /{ }^{137} \mathrm{Cs}$. 


\section{STANDARD ERRORS OF BURNUP OR PU/U RATYO FROM NONDESTRUCTIVE MEASUREMENT OF ${ }^{137} \mathrm{Cs}$ ACTIVITY}

\begin{tabular}{|c|c|c|c|c|c|}
\hline $\begin{array}{l}\text { Reactor } \\
\text { (Type) } \\
\text { Fuel Cycle }\end{array}$ & $\begin{array}{c}\text { Correlation } \\
\text { Between }\end{array}$ & $\begin{array}{c}\text { Standard } \\
\text { Error" } \\
(\%)\end{array}$ & $\begin{array}{c}\text { Burnup } \\
\text { Range } \\
\text { (MWD/MTU) }\end{array}$ & $\begin{array}{c}\text { Source } \\
\text { Configuration }\end{array}$ & Reference No \\
\hline $\begin{array}{l}\text { Trino (PWR) } \\
\text { 2nd Cycle }\end{array}$ & $\mathrm{Bu},{ }^{2 n} \mathrm{Cs}$ & 4.1 & 15000.28000 & Rod & 19 \\
\hline $\begin{array}{l}\text { Garigliano } \\
\text { (BWR) }\end{array}$ & $\mathrm{Bu},{ }^{117} \mathrm{Cs}$ & 1.5 & $9000-12000$ & Rod & 20 \\
\hline $\begin{array}{l}\text { Trino (PWR) } \\
\text { 2nd Cycle }\end{array}$ & $\begin{array}{l}\mathrm{Bu},{ }^{b}{ }^{119} \mathrm{Cs} \\
\mathrm{Pu}^{, 13 r} \mathrm{Cs}\end{array}$ & $\begin{array}{l}2.3 \\
1.8\end{array}$ & 19000.22000 & Assemblyc & $21-22$ \\
\hline $\begin{array}{c}\text { Trino (PWR) } \\
\text { 3rd Cycle }\end{array}$ & $\mathrm{Bu},{ }^{b}{ }^{12 r} \mathrm{Cs}$ & 2.5 & $19700-28700$ & Assembly ${ }^{\mathrm{c}}$ & 23 \\
\hline $\begin{array}{l}\text { Garigliano } \\
\text { (BWR) }\end{array}$ & $\mathrm{Bu},{ }^{\mathrm{b}}{ }^{18 r} \mathrm{Cs}$ & 1.5 & $7000-18500$ & Ássembly ${ }^{\mathrm{e}}$ & 12 \\
\hline $\begin{array}{l}\text { Bohunice } \\
\text { (CANDU-type) }\end{array}$ & $\mathrm{Bu},{ }^{17 n} \mathrm{Cs}$ & 6 & $1800-8000$ & Bundle & 15 \\
\hline \multicolumn{6}{|c|}{$\begin{array}{l}\text { The standard error is calculated, whenever possible, by fitting the data to a linear regression equa- } \\
\text { tion } \mathrm{Y}=\mathrm{a}+\mathrm{bx} \text {. The standard error about the regression }=\end{array}$} \\
\hline \multicolumn{6}{|c|}{$\begin{array}{l}\text { where } y=\text { experimental values, } Y=\text { values predicted from the regression line, and } n=\text { number of } \\
\text { observations. }\end{array}$} \\
\hline $\begin{array}{l}\text { Assemblies were } \mathrm{m} \\
\text { ummed. }\end{array}$ & ed at eight to ni & anc & $\mathrm{rs}$, and the & was & \\
\hline
\end{tabular}

For an absolute activity measurement, absolute detector efficiency must be known, and the measurement must be performed under strictly controlled geometry. The activity ratio measurement, however, is less sensitive to the geometrical arrangement and requires only that the relative detector efficiency be known. This distinct advantage makes the activity ratio measurement much more suitable for use in field inspection. However, a disadvantage is that effective fission yields of the activity ratios are unknown. Thus, to deduce burnup, correlations between burnup and activity ratios must be determined empirically. Correlations have been observed between the burnup or $\mathrm{Pu} / \mathrm{U}$ mass ratio and the ${ }^{134} \mathrm{Cs} /{ }^{137} \mathrm{Cs}$ activity ratio. There are also indications of a possible correlation with the ${ }^{164} \mathrm{Eu} /{ }^{157} \mathrm{Cs}$ activity ratio. These correlations are rather limited and it is doubtful whether such simple correlations exist for BWR fuels. To obtain burnup or plutonium content 
of fuel assemblies, correlations should be determined for each irradiation batch, or at least for each reactor. The status of the correlations will be reviewed later.

A recent improvement in the activity ratio measurement ${ }^{28-28}$ is to introduce an intrinsic calibraiion, where measured intensity ratios for gamma rays of a given isotope are compared with established branching ratios. Using these data, an overall relative efficiency curve tha: includes mass attenuacion and detector efficiency can be determined. This curve can be used to determine the activity ratios of two different isotopes. The advant age of this method is its simplicity; all necessary information to determine the activity ratio (relative efficiency and cooling time) is contained in a single gamma-spectrum measurement. However, this method relies on a fundamental assumption that may or may not be valid in an actual situation. It is accurate only if the measured isotopes $\left({ }^{194} \mathrm{Cs},{ }^{137} \mathrm{Cs}\right.$, ${ }^{19} \mathrm{Eu}$ ) have the same spatial distribution within the assembly. The inaccuracy caused by different isotopic spatial distributions may be significant.

A typical experimental arrangement is shown in Fig. 4 (from Ref. 14). Other activity ratios could also be used, such as the ${ }^{108} \mathrm{Rh} /{ }^{144} \mathrm{Pr}$ suggested in Ref. 13 . However, there is no experimental support for such a correlation, and this ratio may be sensitive to migration effects (see ${ }^{108} \mathrm{Rh}$ profile in Fig. i).

1. ${ }^{194} \mathrm{Cs} /{ }^{137} \mathrm{Cs}$. The results of recent studies of the ${ }^{194} \mathrm{Cs} /{ }^{197} \mathrm{Cs}$ activity ratio as a burnup monitor are summarized in Table III. Table III shows that for PWR fuels, correlations apparently exist between burnup or $\mathrm{Pu} / \mathrm{U}$ mass ratio and ${ }^{139} \mathrm{Cs} /{ }^{157} \mathrm{Cs}$ activity ratio (within 1 to $4 \%$ ) for Trino and Sens reactor spent fuels. The correlation is far from sstablished for BWR fuels. With Garigliano reantor fuel assemblies, ${ }^{12}$ no correlation can be established; with JPDR-I reactor fuel rods, ${ }^{20.30}$ the coryelation separates into two straight lines, depending on the upper or lower parts of the fuel, and for the two portions, the interceptions differ by $20 \%$.

The latier study also found that the ${ }^{184} \mathrm{Cs} /{ }^{137} \mathrm{Cs}$ activity ratio is sensitive to the epithermal-to-thermal flux ratio. The correlations for the two segments can be made to agree better if the appropriate flux correction is made. This is not surprising consider-

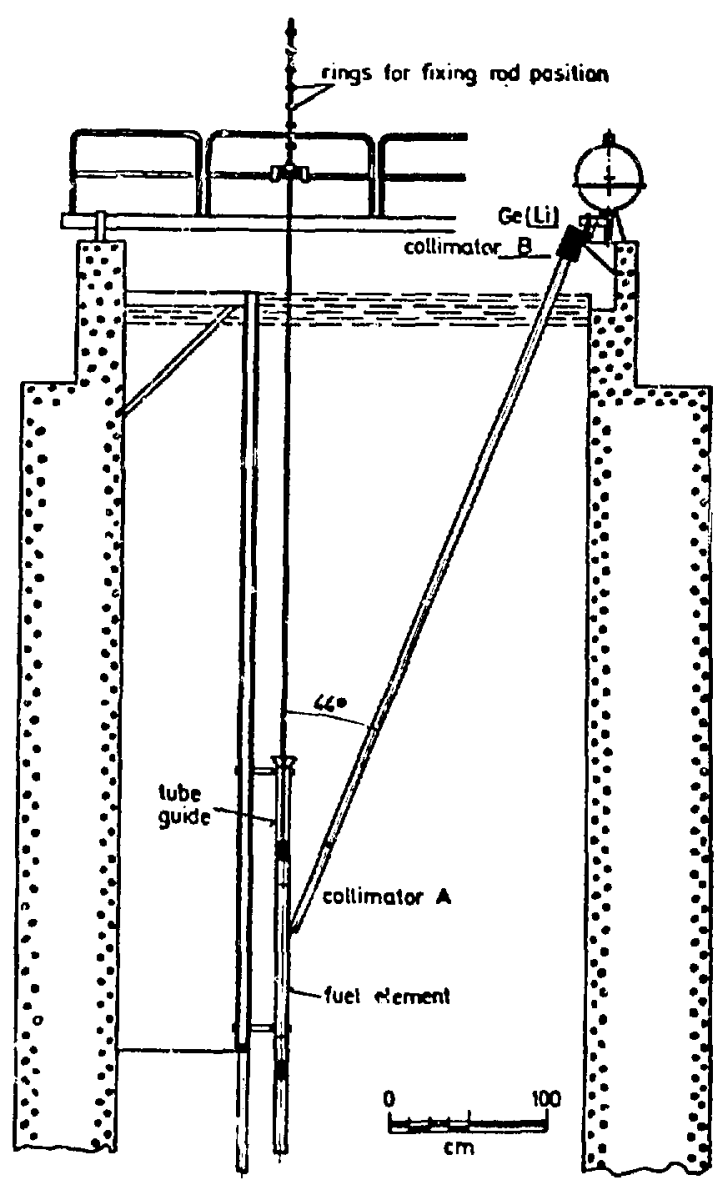

Fig. 4.

Typical gamma activity ratio measuring equipment.

ing that the thermal-neutron-capture cross section and resonance integr al of ${ }^{133} \mathrm{Cs}$ are 30 and 450 harns, respectively, so that the resonance capture reaction is much more probable than thermal-neutron capture. In contrast, the formation of ${ }^{137} \mathrm{Cs}$ depends predominantly on the thermal flux.

It should be emphasized that because the Trino and Bohunice reactors have been studied well, and their attenuation factors can be calculated accurately, standard errors are small (1 to $7 \%$ ).

Some theoretical studies ${ }^{12,22,31}$ have been made to evaluate the correlations between burnup or $\mathrm{Pu} / \mathrm{U}$ mass ratio and ${ }^{134} \mathrm{Cs} /{ }^{197} \mathrm{Cs}$ activity ratios. Reactor parameters that seem to influence the correlations are fuel enrichment, power history, void fraction (BWR), and moderator-to-fuel ratio. 
TABLE III

\section{STANDARD ERRORS OF BURNUP OR PUU RATIO FROM NONDESTRUCTIVE MEASUREMENT OF ${ }^{134} \mathrm{Cs} /{ }^{137} \mathrm{Cs}$ ACTIVITY RATIO}

\begin{tabular}{|c|c|c|c|c|c|c|}
\hline $\begin{array}{c}\text { Reactor } \\
\text { (Type) } \\
\text { Fuel Cycle } \\
\end{array}$ & $\begin{array}{c}\text { Correlation } \\
\text { Eetween }\end{array}$ & & $\begin{array}{c}\text { Standard } \\
\text { Erros" } \\
(\%)\end{array}$ & $\begin{array}{c}\begin{array}{c}\text { Burnup } \\
\text { Range } \\
\text { (MWD/MTU) }\end{array} \\
\end{array}$ & $\begin{array}{c}\text { Source } \\
\text { Configuration }\end{array}$ & $\begin{array}{c}\text { Reference } \\
\text { No. } \\
\end{array}$ \\
\hline $\begin{array}{l}\text { Sena (PWR) } \\
\text { 1st cycle }\end{array}$ & ${ }^{\mathrm{In}} \mathrm{Cs}$, & $\frac{{ }^{2 a c} \mathrm{Cs}}{{ }^{177} \mathrm{Cs}}$ & 3 & $12600-13150$ & Rod & 32 \\
\hline $\begin{array}{l}\text { Sena (PWR) } \\
\text { 2nd cycle }\end{array}$ & ${ }^{119} \mathrm{Cs}_{\text {, }}$ & $\frac{{ }^{124} \mathrm{Cs}}{{ }^{127} \mathrm{Cs}}$ & $13^{b}$ & $18600-20300$ & Rod & 32 \\
\hline $\begin{array}{l}\text { Sena (PWR) } \\
\text { 1st cycle }\end{array}$ & $\mathrm{Bu}$, & $\frac{{ }^{110} \mathrm{Cs}}{{ }^{117} \mathrm{Cs}}$ & 3.7 & $12600-13150$ & $\begin{array}{l}\text { Assembly } \\
\text { midpoint }\end{array}$ & 27 \\
\hline \multirow[t]{2}{*}{$\begin{array}{l}\text { Trino (PWR) } \\
\text { 2nd cycle }\end{array}$} & $\mathrm{Bu}^{\mathrm{c}}$ & $\frac{{ }^{114} \mathrm{Cs}}{{ }^{117} \mathrm{Cs}_{s}}$ & 1.1 & $18500-22500$ & Assembly ${ }^{\curvearrowleft}$ & $21 \cdot 22$ \\
\hline & $\frac{P u^{c}}{U}$ & $\frac{{ }^{114} \mathrm{Cs}}{{ }^{117} \mathrm{Cs}}$ & 1.2 & & & \\
\hline $\begin{array}{l}\text { Trino (PWR) } \\
\text { 3rd cycle }\end{array}$ & $\frac{P u^{e}}{U}$ & $\frac{{ }^{11} \mathrm{Cs}}{{ }^{17} \mathrm{Cs}}$ & 2.1 & $19700-28700$ & Assembly ${ }^{a}$ & 23 \\
\hline $\begin{array}{l}\text { Dodewaard } \\
\text { (BWR) }\end{array}$ & $\mathrm{Bu}$, & $\frac{n \mathrm{Cs}}{{ }^{n} \mathrm{Cs}}$ & 8.5 & $6000-17000$ & Fod & 18 \\
\hline $\begin{array}{l}\text { JDPR-I } \\
\text { (BWR) }\end{array}$ & $\mathrm{Bu}$, & $\frac{{ }^{M 4} \mathrm{Cs}}{{ }^{n+} \mathrm{Cs}}$ & $\begin{array}{l}\text { upper and } \\
\text { lower segments } \\
\text { differ by } 20 \%\end{array}$ & 1900.7000 & Rod & $29-30$ \\
\hline $\begin{array}{l}\text { Garigliano } \\
\text { (BWR) }\end{array}$ & $\frac{\mathrm{Pu}}{\mathrm{J}}$ & $\frac{{ }^{m} \mathrm{Cs}}{{ }^{m} \mathrm{Cs}}$ & no correlation ${ }^{\circ}$ & $7000-18500$ & Assembly ${ }^{d}$ & 12 \\
\hline $\begin{array}{l}\text { Bohunice } \\
\text { (CANDU-Type) }\end{array}$ & B'l, & $\frac{{ }^{n+} \mathrm{C}_{\mathrm{B}}}{{ }^{{ }^{m} \mathrm{Cs}}}$ & $5-7.6$ & $1800-8000$ & Bundle & 15 \\
\hline NPD (CANDU) & $\mathrm{Bu}$ & $\frac{m \mathrm{Cs}}{{ }^{m} \mathrm{Cs}}$ & $1-7.3$ & $6000-10150$ & $\begin{array}{l}\text { Bundle } \\
\text { midpoint }\end{array}$ & 33 \\
\hline \multirow[t]{2}{*}{ PRTR' } & $\mathrm{Bu}$, & $\frac{{ }^{23 \prime} \mathrm{Cs}}{{ }^{m} \mathrm{Cs}}$ & 2.0 & $9000-14000$ & Rod & 2 \\
\hline & $\frac{P_{u}}{U}$, & ${ }^{211} \mathrm{Cg}$ & 1.3 & & . & \\
\hline
\end{tabular}

-The standard error is calculated, whenever possible, by fitting the data to a linear regression equation $Y=a+b x$. The standard erior about the regression $=$

$$
\sqrt{\sum_{i=1}^{n}\left(y_{i} \cdot Y_{i}\right)^{2} /(n-2)} .
$$

where $y=$ experimental values, $Y=$ values predicted from the regression line, and $\mathrm{n}=$ number of observations.

'The error quoted is systematic error. This deviation is attributed to the lack of power history correction.

'Calculated burnup and $\mathrm{Pu} / \mathrm{U}$ ratios.

Assemblies were assayed at eight to nine levels and four corners, and the ${ }^{131} \mathrm{Cs}$ and ${ }^{37} \mathrm{Cs}$ activity ratios were summed.

-If power history correction is made, the standard crror is $3.9 \%$ (Ref. 23 ).

'Plutonium recycle test reactor with naturally enriched uranium oxide fuel. 
Because the half-life of ${ }^{134} \mathrm{Cs}$ is $2.06 \mathrm{yr}$, a correction for the decay, based on operating power history, is recessary for long irradiation. The correction can be applied relatively simply by using weighted burnup, ${ }^{27}$ or fairly elaborately by using burnup codes such as FLARE or PDQ. Perhaps a correction method using the transmutation equation would be sufficiently accurate and simple to apply.

The possible error in the intrinsic calibration method is considered next. This method relies on a fundamental assumption that mass attenuations of ${ }^{194} \mathrm{Cs}$ and ${ }^{137} \mathrm{Cs}$ gamma rays through the assembly are related by the same energy-dependent function. This assumption is correct only if the measured isotopes $\left({ }^{139} \mathrm{Cs},{ }^{137} \mathrm{Cs}\right)$ have the same spatial distribution within the assembly. Different isotopic spatial distributions may be caused by nonuniform burnup across the assembly and/or by different migrations within the fuel pins. It is generally accepted thar. ${ }^{237} \mathrm{Cs}$ activity is proportional to burnup. If the ${ }^{184} \mathrm{Cs} /{ }^{137} \mathrm{Cs}$ activity ratio is also proportional to burnup, then the ${ }^{194} \mathrm{Cs}$ activity should be proportional to the square of the ${ }^{25} \mathrm{Cs}$ activity. Thus, for nonuniform burmup, the ${ }^{134} \mathrm{Cs}$ and ${ }^{137} \mathrm{Cs}$ isotopes would have different distributions across the assembly even if there is no migration.

To estimate the possible uncertainty caused by different activity distributions in the intrinsic calibration method, the following calculations were performed for an 8-by-8 BWR assembly. The corner rods were assumed to have $20 \%$ higher burnup than the central rods, whereas burnups of the otker rods were linearly interpolated. (Postirradiation examinations show burnup variations as high as $\left.40 \% .{ }^{20}\right)$ A Monte Carlo gamma transport code was used to calculate the gamma-ray transmiscicn from the assembly. The collimator, viewing the corner of the assembly, was considered to be perpendicular to the length of the fuel assembly, which was sub. merged in water. The transmission is defined as the ratio of the number of gamma rays that reach the detector at their emitted entergy to the number of gamma rays from the fuel assembly with a trajectory that would pass through the collimator and reach the detect. $r$. The ${ }^{137} \mathrm{Cs}$ activities were distributed proportionally to the burnups within the assembly (Fig. 5).

From the calculated transmissions for various ${ }^{234} \mathrm{Cs}$ gamma-ray peaks (two are shown as squares in

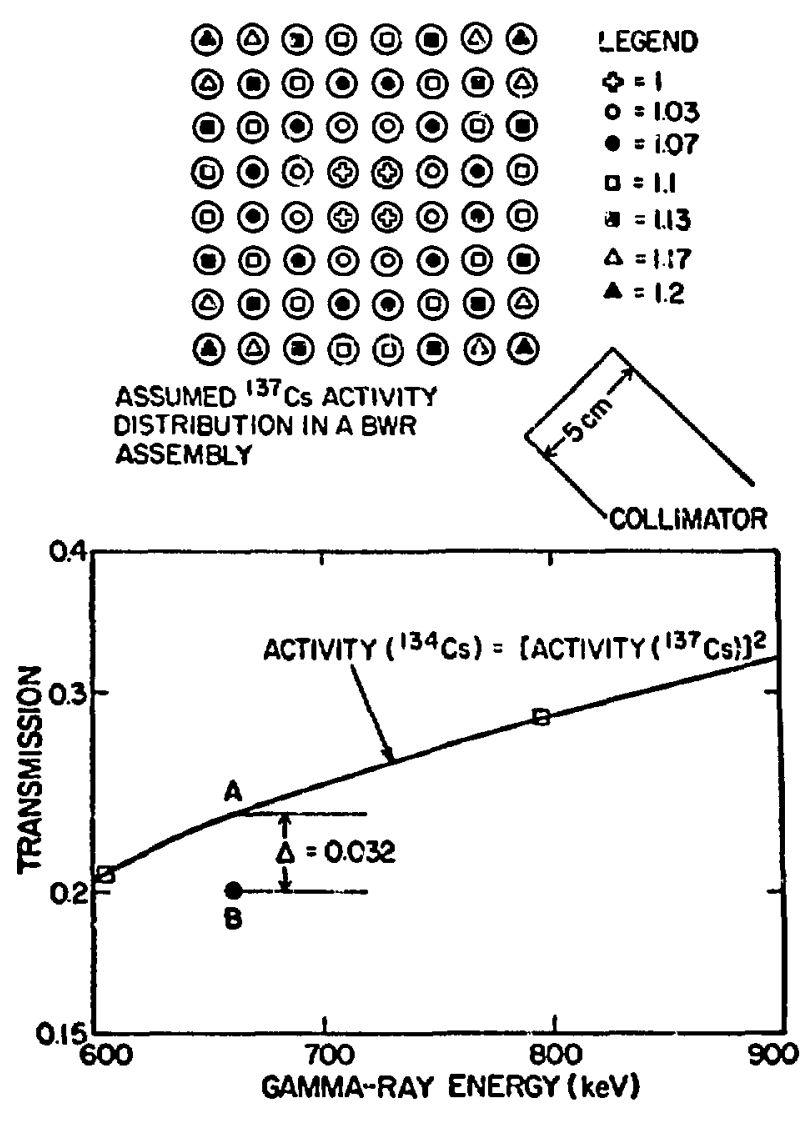

Fig. 5.

Error $(\Delta)$ in the intrinsic calibration method caused by a $20 \%$ nonuniform burnup. Point $A$ is the transmission through the assembly at $662-k e V$ gamma, interpolated from various ${ }^{194} \mathrm{Cs}$ gamma-ray peaks. Point $B$ is transmission from actual ${ }^{137} \mathrm{Cs}$ activity distribution.

the lower half of Fig. 5), the transmission at the 662$\mathrm{keV}$ gamma was interpolated to be $0.233 \pm 0.002$ (point A in Fig. 5). However, the transmission at the same energy from the ${ }^{137} \mathrm{Cr}$ activity distribution was calculated to be $0.201 \pm 0.002$ (point $B$ ). The difference in these transmissions, $16.1 \pm 1.5 \%$, is the error expected in the intrinsic calibration method. This error is the result of a $20 \%$ nonuniform burnup across the assembly; the higher the nonuniformity, the larger the error.

The possible error in the intrinsic calibration method was also calculated for a collimator angle of $45^{\circ}$ to the length of the fuel assembly. Under these conditions, assuming a $20 \%$ nonuniform burnup 
across the assembly, the intrinsic calibration method could be in error by $16.8 \%$. Clearly, corrections for nonuniform burnup and migration must be applied to the intrinsic calibration method.

2. ${ }^{15} \mathrm{Zuw}^{1297} \mathrm{Cs}$. To avoid complications caused by detay during irradiation or power history correction. the ${ }^{284} \mathrm{Eu} /{ }^{137} \mathrm{Cs}$ activity ratio can be used. The $8.6-\mathrm{yr}$ half-life of ${ }^{15} \mathrm{Eu}$ makes power history a minor, or negligible, correction. However, the thermal neutron-capture cross section of ${ }^{15} \mathrm{Eu}$ is relatively high $(1500 \mathrm{~b})$ and this activity ratio is calculated to be proportional only up to $20000 \mathrm{MWD} / \mathrm{MTU}$ burnup. ${ }^{22.23}$ Because the fission yield of ${ }^{165} \mathrm{Eu}$ is much smaller than that of ${ }^{199} \mathrm{Cs}$, the ${ }^{104} \mathrm{Eu}$ activity can be measured only after a long cooling time.

Only a few experimental points exist for the burnup vs ${ }^{264} \mathrm{Eu} /{ }^{137} \mathrm{Cs}$ activity ratio correlation. For the Trino (PWR) assembly assay, correiations were found for burnup vs ${ }^{104} \mathrm{Eu} /{ }^{187} \mathrm{Cs}$ (within $5.5 \%$ ), and for $\mathrm{Pu} / \mathrm{U}$ vs ${ }^{264} \mathrm{Eu} /{ }^{13 \prime} \mathrm{Cs}$ (within $2.5 \%$ ). ${ }^{22}$ For the JPDR.I (BWR) fuel, ${ }^{28.30}$ the burnup vs ${ }^{164} \mathrm{Eu} /{ }^{197} \mathrm{Cs}$ correlation again separated into two straight lines, corresponding to the upper and lower halves of the fuel pin, indicating that this correlation is also sensitive to the void fraction.

\section{F. MTR Sqent Fuel}

Burnup determination of jnaterials testing reactor (MTR) assemblies is simplnr than for LWR assemblies because (1) practically only ${ }^{295} U$ fissions take place, (2) the maximum fuel temperatures during irradiation are relatively low; there is probably little or no migration of fission products, and (3) attenuation cerrection can be taken into account more accurately. However, the irradiation histories are usually more irregular for these research reactors than for power reactors. This makes power history correct in more complicated.

Since the early work by Rasmussen et al., "there have been several experiments on MTR spent fuel. Tzou and Yang, ${ }^{35}$ who used the absolute ${ }^{137} \mathrm{Cs}$ activity measurement method and a somewhat difierent approach to power history correction, found an $\sim 1 \%$ uncertainty in burnup determination. Using the activity ratio method, Beets et al. ${ }^{33}$ measured 21 MTR fuel assemblies and found that the calculated and measured ${ }^{134} \mathrm{Cs} /{ }^{13} \cdot \mathrm{Cs}$ activity ratios had a correlation factor of 0.91 and a relative error of $9 \%$. Dragnev et al..$^{\mathrm{s}}$ measured $16 \mathrm{MTR}$ fuel assemblies and found that between declared burnups and burnups from the measured ${ }^{184} \mathrm{Cs} /{ }^{187} \mathrm{Cs}$ activity ratios the differences ranged from $U$ to $22.7 \%$, with an average difference of $4.9 \%$. In the last two experiments mentioned, the assemblies were measured at midassembly only; the possible axial burnup variation from one assembly to another may be responsible for soine error in the burnup determination.

The absorption measurement method may also be used to determine MTR assembly kurnup. Kreyger et al. ${ }^{37}$ demonstrated that by measuring the $145-\mathrm{keV}$ gamma-ray absorption, the burnup determinations of MTR fuel elements can be accurate to more than $2 \%$ of the initial uranium content.

\section{NEUTRON MEASUREMENTS}

Neutron counting has several advantages over ganıma-ray assay of spent fuels. Active neutron interrogation offers the possibility of assaying the spent-fuel fissile content directly, whereas in the gamma -ray assay, the fissile content can only be inferred. Fast neutrons have relatively high penetrability in nuclear fuel material, thus attenuation correction is less critical. Also, because the halflives of uranium and plutonium isotopes are relatively long, there is little or no reason to correct for decays during irradiation or cooling periods of the fuel. Neutron assay can be made immediately after discharge, but gamma-ray assay can be made only after a certain cooling period.

However, neutron assay involves gross counting and it is impossible to say which isotope is the source of the measured neutrons. Neutron counting is also influenced by the presence of moderators and neutron poisons that may cause errors in the assay. Furthermore, the generic active neutron interrogation system is heavily shielded and therefore not easily portable. Thermal-neutron interrogation requires self-shielding corrections that may or may not be determined easily. 


\section{A. Passive Neutron Counting}

Irradiated fuels normally have a relatively high neutron emission rate $\left(10^{7}\right.$ to $10^{8} \mathrm{n} / \mathrm{s}$ per assembly), but passive neutron counting has not been actively considered as a possible method to determine burnup. The neutron emission rate depends on the quantity of curium isotopes in the fuel. A recent postirradiation examination of Trino fuel ${ }^{19}$ shows that the ${ }^{242} \mathrm{Cm}$ and ${ }^{244} \mathrm{Cm}$ activities are proportional to burnup from 13000 to $27000 \mathrm{MWD} / \mathrm{MTU}$.

With uranium, plutonium, and americium isotopic compositions from this study, ${ }^{10}$ neutron yields from each isotope can be calculated. Figure 6 shows neutron yield at various cooling times for a relatively high burnup fuel sample. At discharge, most of the passive neutrons originate from the

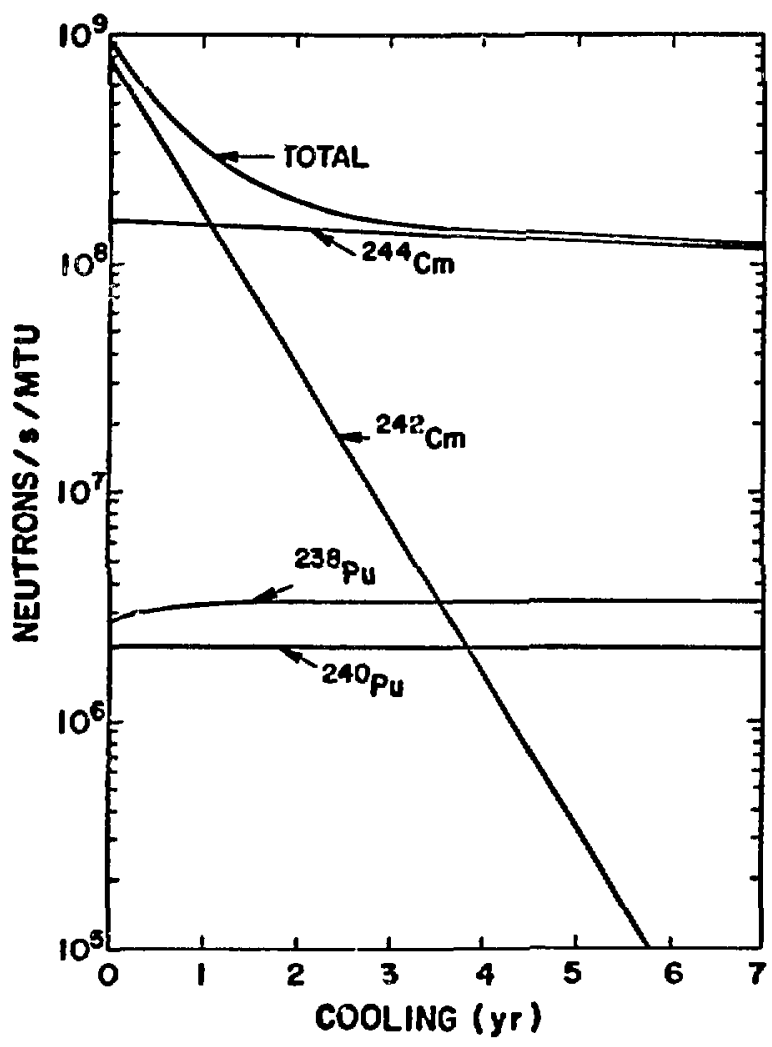

Fig. 6.

Neutrons per second from ${ }^{290} \mathrm{Pu},{ }^{240} \mathrm{Pu},{ }^{242} \mathrm{Cm}$, and ${ }^{24} \mathrm{Cm}$ isotopes at a burnup of 26884 $M W D / M T U$. The total number of neutrons includes contributions from the other uranium, plutonium, and americium isotopes of the Trino reactor fuel.
${ }^{242} \mathrm{Cm}$ isotope; 2 yr after discharge, most of the neutrons o:iginate from the ${ }^{241} \mathrm{Cm}$ isotope. Figure 7 shows total neutrons emitted per second as a function of burnup. At discharge, total neutrons emitted per second is a linear function of burnup from 13000 to $27000 \mathrm{MWD} / \mathrm{MTU}$. After $2 \mathrm{yr}$ cooling, the total neutrons emitted per second are proportional to burnup from 18000 to 27000 MWD,MTU. For burriups $<18000 \mathrm{MWD} / \mathrm{MTU}$, the contributions from ${ }^{200 \mathrm{Pu}}$ and ${ }^{2 s 8} \mathrm{Pu}$ isotopes are significant. Aíter $>2 \mathrm{yr}$ cooling, the neutron emission :ate is still proportional to the burnup over the same range.

Passive neutron assay can be used as a consistency check over the burnup range of 18000 to $27000 \mathrm{MWD} / \mathrm{MTU}$ for various cooling times, and over a wider burnup range at discharge. This conclusion is drawn from the Trino reactor fuel; it is not certain however that the number of curium isotope atoms is proportional to burnup for other reactor fuels. The passive neutron assay of burnup is a promising alternative to gamma-ray assay and should be investigated further. If the assay is to be performed under water, neutron multiplication effects may 'je significant.

\section{B. Active Interrogation with Isotopic Source}

1. LWR Spent-Fuel Assay System. Gozani ${ }^{98,39}$ reported a feasibility study on an assay system using the layout shown in Fig. 8. The system consists of

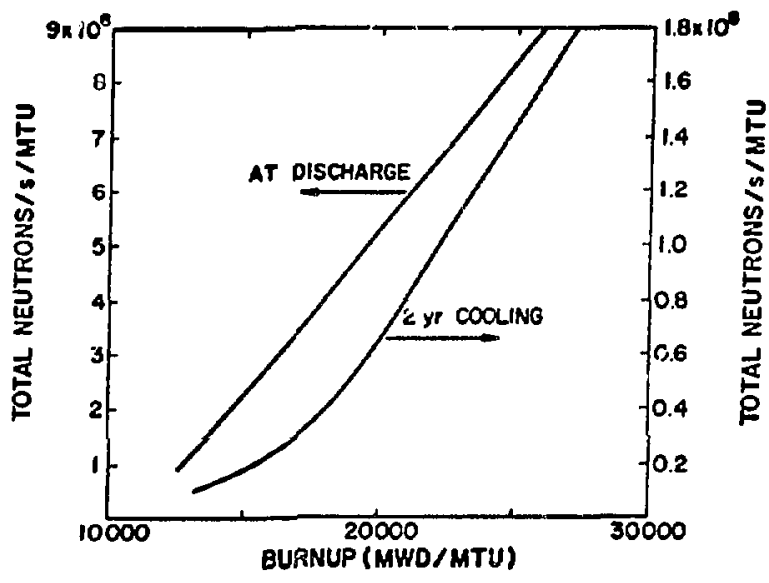

Fig. 7.

Total number of neutrons per second vs burnup at discharge and after $2 y r$ cooling for the Trino reactor fuel. 


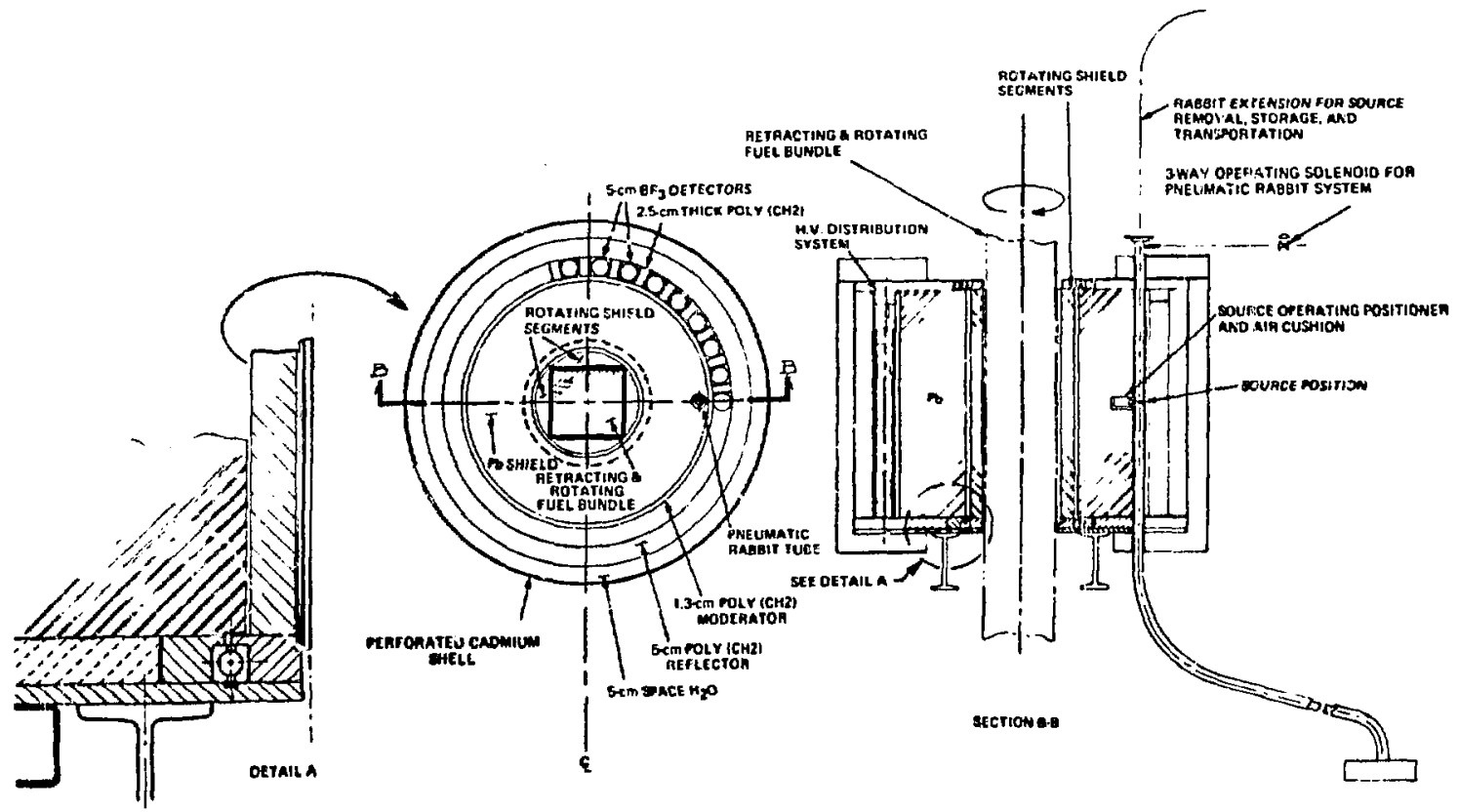

Fig. 8.

Conceptual design of an LWR fuel assembly assay system.

either a ${ }^{252} \mathrm{Cf}$ or an antimony-beryllium neutron source that can be shuffled for prompt-and delayedneutron counting.

The main (acceptable) conclusion of this study is that an assay system can be built to determine the fissile content of LWR spent fuel; there are, however, reasons to disagree with some specific points of the study. With ${ }^{202} \mathrm{C} f$ interrogation and proinpt-neutron counting, the detectors near the source should be deleted because they reduce the fission-to-source-neutron discrimination ratio. Measurements have shown ${ }^{\Delta a}$ that $\mathrm{BF}_{\mathrm{s}}$ neutron detectors are not suitable for use in the high neutron fields of either the spent fuel or the interrogation source in that they do not recover rapidly for delayed-neutron counting. The possibility of measuring uranium and plutonium fissile contents separately by using either the delayed-tc-prompt ratios or the gadolinium filtered and unfiltered measurements, could be difficult to achieve in practice.

This approach, or a modified version, can probably be used to assay the fissile content of spent fuel with reasonable accuracy; for this purpose, prompt-neutron counting has the advantage of the better signal-to-background ratio. A similar system using prompt-neutron response to determine fissile content by interrogating with rhodium-deuterium neutron sources was proposed by Ragan et al..1 for FBR fuel. They concluded that the system could assay the fissile content with 1 to $5 \%$ uncertainty. However, this type of LWR spent-fuel assay system has not been built. Baumung et al. ${ }^{42}$ reported a similar system for assay of fresh fuel assembiies that combines irradiation by an antimony-beryllium neutron source, fuel bundle rotation, and promptneutron detection.

\section{Highly Enriched Spent-Fuel Assay System.} Highly enriched spent fuels are simpler to assay because of the higher fissile content (mostly ${ }^{280} \mathrm{U}$ ), and the reduced neutron background.

Augustson et al. ${ }^{48}$ designed and operated an automated system for the slightly irradiated, $93 \%$ enriched Rover fuel accumulated from the U.S. Nuclear Rocket Propulsion program. Up to seven fuel rods were put in cardboard tubes and assayed by active neutron interrogation. The assay system, shown in Fig. 9, consisted of two radium-beryllium sources and ${ }^{4} \mathrm{He}$ gas proportional counters for 


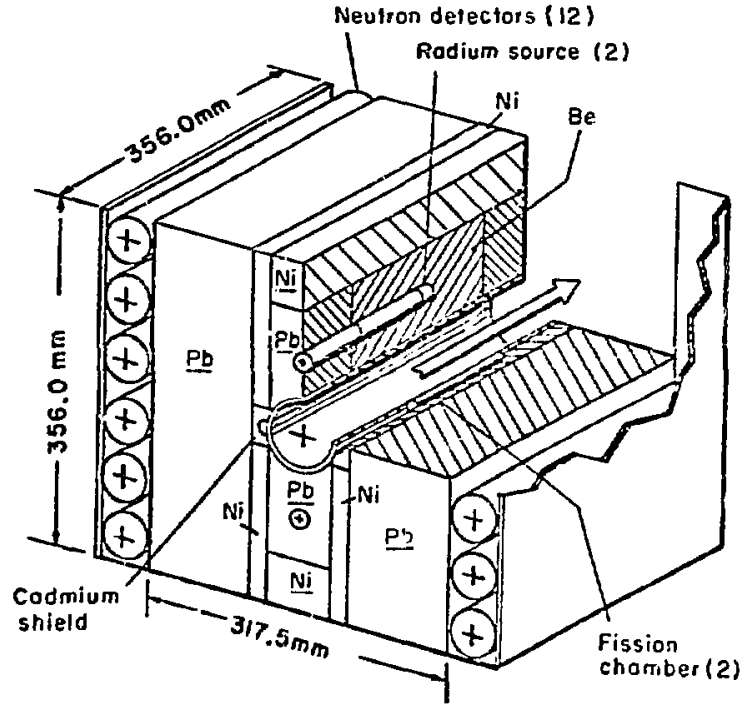

Fig. 9.

Irradiation region of the radium $(\gamma, n)$ beryllium assay system for measuring ${ }^{230} U$ content in irradiated Rover fuel rod tubes.

prompt-neutron detection. To correct for the neutron thermalization caused by the cardboard tubes, two fission chambers were used as flux monitors near the sample. Tests of the axial and radial material distributions within the assay tube showed that the response was quite independent of material distributions. The assay system was calibrated with a series of seven standards identical in geometry and packaging to the unknown tubes. A 150 -s assay showed a typical $2.1 \%(2 \sigma)$ uncertainty in the ${ }^{205} \mathrm{U}$ mass. Numerous field tests were run in which more than 2000 tubes were assayed. The total assayed fissile content amounted to $99.44 \%$ of the book value, indicating little or no bias. For higher burnup fuels, the system may need some slight modification to shield the detectors better and to measure the self-interrogation from the fission. product gamma rays.

Filss ${ }^{44,46}$ reported a system that can assay hightemperature gas-cooled reactor (HTGR) spent fuels in 6-cm-diam spheres. This system used two antimony-beryllium sources for active neutron interrogation. Fission and source neutrons were separated by transport differences in boronpoisoned water. For well-characterized samples like the HTGR spheres, thermal interrogation was reconmended. The self-shielding effect could be determined by a series of standards. The uncertainty in the fissile content determination of this system was $4 \%$.

\section{Active Interrogation with an Accelerator}

1. LWR Spent-Fuel Assay. No experiment has been performed using accelerators to assay LWR spent-fuel assemblies. However, a study was made by Weisbin et al. ${ }^{48}$ using 200 - to $500-\mathrm{keV}$ neutrons produced from a Van de Graaff accelerator to interrogate fresh fuel assemblies. A steel reflector around the assembly flattened the ${ }^{236} \mathrm{U}$ spatial response within the assembly. Both prompt and delayed signals were measured. For a 30-min assay, the ${ }^{235} \mathrm{U}$ content of an entire fvel assembly could be measured with an overall $2 \%$ uncertainty. The possibility of differentiating the ${ }^{298} \mathrm{U}$ and ${ }^{230} \mathrm{Pu}$ fissile contents by a prompt-to-delayed-response ratio was mentioned but not demonstrated. The same assay technique, with some simple modifications, such as adding lead shielding around the steel reflector, should be applicable to the assay of an irradiated fuel assembly.

\section{Highly Enriched Spent-Fuel Assay.} Augustson et al. ${ }^{47}$ performed an experiment to assay the fissile content of MTR-type spent fuel using the delayed-neutron yield technique. A CockcroftWalton accelerator producing $14-\mathrm{MeV}$ neutrons by the $(D, T)$ reaction was used for interrogation. The neutron spectrum was moderated by $2 i .5 \mathrm{~cm}$ of lead (mainly from the shipping cask) to enhance fissile response compared with fertile materials. A correction was made for the delayed-neutron response from the fertile isotopes. A fresh fuel element was used as the calibration standard. Over a wide range of loadings (250 to $340 \mathrm{~g}$ ), the assay was accurate to within $2 \%$ with a measurement standard deviation of $0.6 \%$.

Rotter ${ }^{\text {s8 }}$ has reported an assay method using a sealed pulsed-neutron tube for interrogation. The shape of the prompt-neutron response (first and second time moments measured 100 to $600 \mu$ s after pulsing) could be used to discern poison and the fissile content in the fuel element. For highly 
enriched spent fuels, the fissile content was determined to within an accuracy of $\sim 4 \%$ and the poison content to within $7 \%$. Rotter claimed that the assay method could be used on LWR fuel elements with little or no modification.

\section{Slowing-Down Spectrometer}

A slowing-down spectrometer (SDS) has been proposed ${ }^{40,50}$ for assaying spent-fuel rods. Because of the time-energy correlation, the SDS can be considered a neutron interrogation : stem with a variable energy. The ${ }^{295} \mathrm{U}$ and ${ }^{289} \mathrm{Pu}$ fissile contents can be distinguished by differences in the cross sections at certain neutron energies.

Interrogating fresh rods with neutrons of mean energies of 0.025 and $0.3 \mathrm{eV}$, Krinninger et al. ${ }^{40,51}$ report ed that a ${ }^{239} \mathrm{Pu} /{ }^{280} \mathrm{U}$ discrimination factor of 4 could be attained. The relatively large resonance self-shielding at these energies required a careful shielding correction calculation. It was claimed that the ${ }^{295} \mathrm{U}$ and ${ }^{200} \mathrm{Pu}$ contents in fuel rods could be assayed to within a $2 \%(1 \sigma)$ accuracy. ${ }^{\text {st }}$ Baumung ei al..$^{42}$ explored the higher neutron energy regions to reduce the self-shielding correction, but the ${ }^{239} \mathrm{Pu} /{ }^{235} \mathrm{U}$ discrimination factor dropped to $<2$ malsing plutonium and uranium fissile separation difficult.

The problems of assaying spent-fuel rods with SDS have been examined. ${ }^{49.80}$ Fission-product build-up does not appear to affect the assay accuracy. 9 The neutron detectors must operate in a relatively high radiation field or they should be separated from the sample by shielding material. The method loses accuracy in assaying spent-fuel rods because the $1-\mathrm{eV}$ resonance of the unknown ${ }^{20} \mathrm{Pu}$ content may overlap the $0.3-\mathrm{eV}{ }^{23} \mathrm{Pu}$ resonance. Also, it is questionable whether the SDS method can assay the whole assembly because of the nonuniform response across the assembly, and that the increased sample size deteriorates the energy resolution.

\section{E. Neutron Resonance Abscrption}

Individual plutonium and uranium fissile contents in spent fuel also can be determingd by neutron resonance absorption analysis. Priesmeyer et al. ${ }^{.2}$ used a fast chopper and time-of-flight (TOF) spectrometer to select the neutron resonances in the 0.2- to 50 -eV energy range. The ${ }^{255} \mathrm{U},{ }^{238} \mathrm{U},{ }^{298} \mathrm{U},{ }^{289} \mathrm{Pu}$, ${ }^{240} \mathrm{Pu}$, and ${ }^{212} \mathrm{Pu}$ isotopes were found to have isolated resonances in this energy range that can be used for assay. The interference from fission-product resonances seems to be negligible. The study indicates that this technique could measure the conats of pulverized pellet samples to within $\sim 10 \%$ accuracy. Lazarev ${ }^{59}$ reported a study on FBR fuel rods where the neutron resonance absorption technique was used, and he quoted an $\sim 2 \%$ measurement uncertainty in ${ }^{230} \mathrm{Pu}$. This technique, however, probably cannot be applied to assay fuel assemblies, excent for certain MTR assemblies, because (1) the absorption from the larger resonances tends to saturate as sarnple thickness increases, and (2) the method requires the sample to be in slab geometry. This method requires an intensive epithermal neutron source (probably from a reactor) and the rather complicated chopper TOF spectrometer.

\section{OTHER MEASUREMENT TECHNIQUES}

Besides the assay techniques based on gamma and neutron measurements, two other NDA techniques reported for irradiated fuel are the reactivity and calorimetric methods, both of which are integral measurements.

\section{A. Reactivity Measurement}

The reactivity measurement has been used for many years to assay nv.clear material. Beyster ${ }^{54}$ evaluated the advantagess and disadvantages of both the critical and subcritical reactivity methods. Reactivity is basically an integral quantity, although poison and fuel content can be differentiated by tailoring the neutron flux or the adjoint flux. In addition to the poison-fissile content separation, Baumung et al. ${ }^{22}$ found that a ${ }^{289} \mathrm{Pu} /{ }^{296} \mathrm{U}$ dis. crimination factor of 2.6 could be achieved with this method. Green et al. ${ }^{85}$ applied the technique to assay ${ }^{238} \mathrm{UO}_{2}-\mathrm{ThO}_{2}$ irradiated rods. They found truat the fission-product reactivity worth is $<3 \%$ of the fuel worth; the spontaneous neutron $\left(6 \times 10^{\mathrm{s}} \mathrm{n} / \mathrm{s}\right)$ 
reactivity is much below the measurement sensitivity $\left(\Delta k / k=10^{-7}\right)$. The total accuracy (systematic and random) for an assay of 500 rods was estimated to be $0.5 \%$.

This assay technique seems to be applicable to whole assemblies, ${ }^{58}$ especially the MTR-type assembly that has a relatively small self-shielding effect. The main problem of the technique to assay an LWR spent assembly is to determine the plutonium and uranium fissile contents of the assembly separately. The cost of such an assay system is relatively high. ${ }^{64}$

\section{B. Calorimetric Measurement}

Another interesting approach to determine spentfuel burnup is to measure its heat output. The heat, generated predominantly from fission products, depends not only on burnup, but on irradiation history and cooling time. Ramthun and Debertin ${ }^{67,58}$ found that the ${ }^{144} \mathrm{Ce}-{ }^{144} \mathrm{Pr}\left(\mathrm{T}_{1 / 2}=284\right.$ days $)$ and ${ }^{89} \mathrm{Sr}+{ }^{81} \mathrm{Y}$ $+{ }^{95} \mathrm{Zr}$ activities $\left(\mathrm{T}_{1 / 2} \cong 60\right.$ days! contributed the major portion of heat generated from MTR fuel sections. They claimed an accuracy of 1.5 to $2.7 \%$ in calorimetric burnup determination and a possible 2 to $3 \%$ systematic error from nuclear data, gammaray energy absorption. It is hard to comprehend that the gross heat measurement can be more accurate than the gamma spectrometric measurement in which the isotopes can be identified by gamma-ray signatures. Perhaps because the authors knew the detailed irradiation history within a maximum 330day irradiation period, careful irradiation history and cooling corrections were possible. Good agreement was obtained between calorimetric and massspectrometric measurements.

\section{v. SUMMARY AND DISCUSSION}

A summary of the status of NDA techniques as applied to spent fuels is given in Table IV. Since the last review in 1968, several NDA techniques have proved reliable to determine burnup or tissile content of irradiated nuclear fuels for safeguards purposes.

\section{A. MTR Spent-Fuel Assemblies}

The status of NDA techniques for MTR or other highly enriched fuel assemblies is quite good. Both the absolute gamma activity and the gamma activity ratio methods can determine burnup of an MTR assembly with reasonable accuracy. If the fissile content of the assembly were desired, either the gamma-ray absorption method or the neutron interrogation with isotopic source method could be used.

\section{B. LWR Spent-Fuel Assemblies}

The status of NDA techniques for LWR fuel assemblies is not yet satisfactory and must be studied further to develop reliable techniques.

To determine burnup, the activity ratio method is desirable for field inspection because of simplicity of measurement. Several aspects of this method, however, require further examination.

1. At present, indications are that no correlation exists between the burnup and the ${ }^{194} \mathrm{Cs} /{ }^{137} \mathrm{Cs}$ activity ratios for BWR assemblies. ${ }^{12}$ More studies are needed to evaluate the influence of obvious reactor variabies (enrichment, poison content, moderatorto-fuel ratio, etc.) on the correlation.

2. Approximately four experiments have been reported in which correlations in LWR spent-fuel assemblies were determined to within $4 \%$. Most of the experiments relied on detailed specific burnup calculations to derive the assembly attenuation corrections. An inspection agency would not have enough information nor time to perform these calculations. Inspectors need a set of empirical correlations between burnups and activity ratios without the attenuation correction. An agreement should be reached between the investigators and inspection agencies that similar measurement techniques (assembly corner measurement, power history correction, etc.) be used in establishing the correla. tions to be relied upon in field inspection. We question whether correlations established from postirradiation examinations of fuel pellets or dissolver solutions can be used to assay fuel assemblies 
TABLE IV

\section{SUMMARY OF NDA TECHNIQUES ON SPENT FUEL}

\begin{tabular}{|c|c|c|c|c|}
\hline Technique & $\begin{array}{c}\text { Gamma Source or } \\
\text { Interrogating Neutron }\end{array}$ & Spent-Fuei Type & $\begin{array}{c}\text { Present } \\
\text { Accuracy }(\%)\end{array}$ & Comments \\
\hline \multirow[t]{2}{*}{ Absolute gamma activity } & ${ }^{\mathrm{m}} \mathrm{Cs}$ & $\begin{array}{l}\text { LWR rod } \\
\text { LWR assembly }\end{array}$ & $\begin{array}{l}1-4 \\
1-6\end{array}$ & $\begin{array}{l}\text { Accuracy can be attained } \\
\text { only if the assembly attenuation } \\
\text { can be calculated to higher } \\
\text { accuracy. }\end{array}$ \\
\hline & & MTR assembly & 1 & \\
\hline Gamma activity ratio & ${ }^{24} \mathrm{Cs} /{ }^{137} \mathrm{Cs}$ & $\begin{array}{l}\text { LWR rod } \\
\text { LWR assembly }\end{array}$ & $\begin{array}{l}3.8 \\
1-4\end{array}$ & $\begin{array}{l}\text { Accuracy can be attained } \\
\text { only if the assembly attenuation } \\
\text { can be calculated to higher } \\
\text { accuracy. }\end{array}$ \\
\hline Gamma-ray absorption & $145-k e V$ gamma ray & MTR assembly & 2 & \\
\hline Passive neutron counting, & & LWR rod & & Needs experimental study. \\
\hline $\begin{array}{l}\text { Neutron interrogation } \\
\text { with isotopic source }\end{array}$ & $\begin{array}{l}\text { a"'Cf, Sb-Be, Rh-D } \\
\text { Ra-Be } \\
\mathrm{Sb} \cdot \mathrm{Be}\end{array}$ & $\begin{array}{l}\text { LWR assembly } \\
\text { Rover fuel } \\
\text { HTGR fuel }\end{array}$ & $\begin{array}{l}2 \\
4\end{array}$ & $\begin{array}{l}\text { Feasibility study only. } \\
\text { System extensively tested. } \\
\text { Systern tested. }\end{array}$ \\
\hline \multirow[t]{3}{*}{$\begin{array}{l}\text { Neutron interrogation } \\
\text { with accelerator }\end{array}$} & $\begin{array}{l}\text { Van de Graaff } \\
\text { (200- to 500-keV neutro.1) }\end{array}$ & LWR assembly & & Feasibility study only. \\
\hline & $\begin{array}{l}\text { Cockcroft-Walton } \\
\text { (i4-MeV neutron) }\end{array}$ & MTR assembly & 2 & System tested. \\
\hline & $\begin{array}{l}\text { Sealed neutron tube } \\
\text { (14-MeV neutron) }\end{array}$ & MTR-type assembly & 4 & System tested. \\
\hline $\begin{array}{l}\text { Slowing-down } \\
\text { spectrometer }\end{array}$ & $\begin{array}{l}\text { Sealed neutron tube } \\
\text { (14-MeV neutron) }\end{array}$ & LWR rod & & $\begin{array}{l}\text { Feasibility study. }{ }^{200} \mathrm{Pu} /{ }^{2 a s} \mathrm{U} \\
\text { discrimination ratio of } 4 \text { has } \\
\text { been achieved for fresh fuel. }\end{array}$ \\
\hline \multirow[t]{2}{*}{$\begin{array}{l}\text { Neutron resonance } \\
\text { absorption }\end{array}$} & $\begin{array}{l}\text { Intense epithermal } \\
\text { neutron }\end{array}$ & LWR fuel powder & 9 & $\begin{array}{l}\text { Can determine the isotopic } \\
\text { content. Probably applicable } \\
\text { to MTR assembly. }\end{array}$ \\
\hline & & FBR rod & 2 & \\
\hline Reactivity & Critical assembly & $\left({ }^{2 n} \mathrm{UO}_{2}-\mathrm{ThO}_{2}\right)$ rod & 0.5 & $\begin{array}{l}\text { Needs investigation to apply } \\
\text { this method to LWR rod or } \\
\text { assembly. }\end{array}$ \\
\hline Calorimetry & & MTR fuel plates & $1-3$ & $\begin{array}{l}\text { Requires careful irradiation } \\
\text { and cooling correction. }\end{array}$ \\
\hline
\end{tabular}

hecause of the very large attenuation factor, unless the intrinsic calibration method is proved valid.

3. The intrinsic calibration method simplifies the activity ratio measurement significantly, but the activity migration and nonuniform burnup cause errors. Changes in the present LWR fuel design could reduce these errors and enhance the usefulness of the method (smaller fuel pin diameter and lower linear power ratings reduce both probability of cesium migration and the influence of the different radial distribution of ${ }^{194} \mathrm{Cs}$ and ${ }^{137} \mathrm{Cs}$; different enrichment loading within the assembly 
enstires a more uniform burnup). Understanding of applicability of the intrinsic calibration method to various generations of reactor fuels is required.

4. A reliable method of scanning the assembly to obtain burnup profiles by some integral gamma or neutron measurement will expedite the measuring process. After determination of burnup profile, only measurement of assembly activity ratio at one or a few points is necessary.

In a gamma assay, the outer rods of a spent-fuel ssembly contribute most of the activity; an alternative method is needed for burnup determination in which the contribution from the center rods is more significant. Passive neutron counting of the fast neutrons appears promising, and the measurement can be performed with portable equipment. Because the possibilities of this method have not been established, it should be explored. If fissile content of LWR fuel is required by an inspection agency, then neutron interrogation with sealed neutron tubes is a possibility, but it has not been actively investigated.

For reprocessing plants, it seems that systems using the approach of neutron interrogation with isotopic sources ${ }^{38,38,41}$ could determine the total fissile content of LWR fuel assemblies. At present, no method can accurately differentiate between the plutonium and uranium fissile contents of the assembly. A method that could differentiate between the two dominant fissile components would be advantageous for a reprocessing facility.

Accuracy of burnup calculations for PWR, BWR, and CANDU reactors is discussed in the Appendix. Based on previous bench-mark calculations, the assembly-averaged burnups can be calculated to within 3 to $7 \%$. However, without detailed simulations of the actual reactor operating history, an additional error (within 5 to $7 \%$ for PWR, 10 to $15 \%$ for BWR) may be made in predicting assemblyaveraged burnups. If a substantial deviation is found between measured and declared burnups, the logical conclusion would be that either fuel substitution has taken place or there is a large error in the declared burnup. Therefore, the inspection agency should have the capability to check the burnup calculation in case of discrepancy.

\section{ACKNOWLEDGMENTS}

We wish to thank R. H. Augustson, N . Bresesti, H. O. Menlove, J. R. Phillips, R. B. Walton, and W. F. Staley for valuable discussions and aid in the preparation of this manuscript.

\section{APPENDIX}

\section{BURNUP PREDICTION CAPABILITY FOR PWR, BWR, AND CANDU REACTORS}

\section{INTRODUCTION}

Strict monitoring of special nuclear materials is necessary to prevent their diversion from legitimate uses to illegal weapons applications. Specifically, the burnup and heavy-element isotopic content of spent fuels from power reactors must be known to detect unsanctioned activities. Various experimental techniques can verify spent-fuel burnup declared by reactor operators. In addition, it is desirable to provide additional verification of declared burnup by comparison with calculated burnup predictions. This Appendix is a brief review of our ability to predict fuel burnup in power reactor cores in order to understand better the usefulness of burnup calculations for nuclear materials safeguards considericions.

Fc: accurate fuel burnup predictions in a power reactor core, we rely heavily on computer code systems to account for material heterogeneities and complex space- and energy-dependence of reaction cross sections of materials in the core, as well as for accurate determination of various nuclide concentrations as a function of fuel burnup. Accurate burnup calculations also require a detailed simulation 
of the actual operating history and fuel management scheme of the reactor core.

During the past decade, the accuracy of fuel burnup predictions in reactor cores has been the subject of several reviews. ${ }^{60-05}$ This report updates earlier reviews by incorporating recent experimental and calculational results. In addition, credit is given to industry's efforts to evaluate and improve the accuracy of power distribution predictions and measurements. The accuracy of fuel burnup predictions is, of course, limited by the difficulty in making accurate power distribution predictions. Here we discuss only the capability for predicting power and burnup distributions in LWR and CANDU reactor cores.

\section{COMPARISON OF REACTOR TYPES}

\section{A. PWR}

The distinctive feature of the PWR design (which represents about two-fifths of the world's operating reactors) is the use of light-water moderator and coolant. The water, at a system pressure of 155 bars (2250 psia or $15.7 \mathrm{MPa}$ ), normally is not permitted to boil in the reactor pressure vessel. The reactor core is further characterized by uniform enrichment within each fuel assembly, small water gaps between assemblies, and a distributed control poison system.

The reactivity variation caused by power level change is controlled by a combination of distributed control rods and boric acid dissolved in the coolant. The gross reactivity change caused by fuel depletion is compensated for by a combination of soluble boron and distributed burnable poisons usually containing $\mathrm{B}_{1} \mathrm{C}$. During normal operations, the control rods are essentially removed from the reactor core. Fuel elements, which typically contain 1.9 to $3.5 \%$ enriched uranium dioxide, are exposed to 33000 MWD/MTU of burnup before discharge.

\section{B. BWR}

The BWR design (which represents about onethird of operating reactors) also uses light-water moderator and coolant. In BWR cores, however, the coolant wrater is at a system pressure of 72 bars ( 1050 psia or $7.3 \mathrm{MPa}$ ) and is allowed to undergo bulk boiling in the reactor core, thus causing an appreciable amount of void formation. The most significant manifestation of this is a strong negative reactivity feedback effect.

Other differences from the PWR design are caused by additional heterogeneities in the core structure. Fuel assemblies with nonuniform enrichment distributions are separated by large water gaps that accommodate control elements. The control elements, in the form of cruciform blades, are strong localized neutron absorbers that usually control reactivity variation associated with power level changes and fuel depletion. Control of reactivity changes caused by load variations may also be augmented by flow rate controls in BWR cores. Control of reactivity variation from fuel burnup is also augmented by distributed burnable poisons consisting of $\mathrm{Gd}_{2} \mathrm{O}_{3}$ mixed with fuel material in selected rod locations. Fuel assemblies, which are typically loaded with uranium dioxide pellets of 1.5 to $3.0 \%$ enrichment, are exposed to $27500 \mathrm{MWD} / \mathrm{MTU}$ of burnup before discharge.

The cruciform control blades also obtain the desired power distribution in BWR cores that, uncontrolled, would be distorted considerably from symmetric distributions caused by the distributed void feedback effect. Thus, at the beginning-ofcycle (BOC) in a BWR core, about a quarter of the control rod full-length equivalent would be inserted into the core so that reactivity and power distribution requirements would be met. Control rods are in terchanged at subsequent intervals in the fuel cycle and are gradually removed until at the end-of-cycle (EOC) the core is free of control rods.

\section{CANDU}

The most distinct feature of the CANDU design is that heavy water serves as both moderator and coolant, which permits the use of natural uranium as fuel instead of enriched uranium (as in LWR designs). In CANDU reactor cores, ${ }^{84}$ slort bundles of fuel rods, typically $50 \mathrm{~cm}$ long, are placed end to end horizontally in individual pressure tubes containing heavy-water coolant. The pressure tubes are 
loaded horizuntally in a calandria, which contains the cool, low-pressure heavy-water moderator.

The CANDU design is also characterized by its on-power, continuous refueling scheme, which minimizes the control requirements associated with fuel depletion. Lumped poisons consisting of cobalt rods and tubes of light water control the reactivity changes associated with power level variation, shape the desired power distribution, and control spatial xenon oscillations. This control system is augmented by a soluble boron system that overrides excess reactivity during the initial phase of reactor operation. About $0.2 \%$ of fuel bundles may be reloaded on a daily basis in a typical CANDU operation, resulting in a discharge burnup of 8000 MWD/MTU.

\section{CALCULATIONAL METHODS FOR BURNUP DETERMINATION}

Various methods have been developed ${ }^{\text {ss }}$ to determine power and burnup distributions in reactor cores, with varying degrees of approximations to the solution of the neutron transport equation. These approximations are necessary because of numerous material heterogeneities, and because of the complex energy dependence of microscopic neutron cross sections over the energy spectrum encountered in reactor cores. One basic approximation in these methods results in a time-dependent isotopic depletion equation co: state solutions for neutron flux and power distributions. The energy- and space-dependent neutron flux distribution is obtained, based on varying degrees of geometric variable separability assumptions.

Power burnup calculations in PWR cores are usually initiated by unit-cell codes, such as LEOPARD, ${ }^{\circ 5}$ which represent individual fuel rods. The few-group microscopic or macroscopic cross sections obtained from these calculations are used in fine-mesh diffusion theory, codes such as PDQ-7, ${ }^{80}$ which simulate individual fuel rods discretely in two-dimensional $x-y$ geometry. These twodimensional $x-y$ calculations are then coupled in a single-channel synthesis scheme with onedimensional axial calculations to generate threedimensional flux and power distributions. The assumption of separability of power distribution in the radial and axial directions is acceptable in PWR cores, where the spatial variation of moderator density is small and the neutron absorbers are nearly uniformly distributed. However, increased efforts have been made recently to perform full threedimensional diffusion theory calculations for PWR cores rather than the traditional radial-axial synthesis calculations.

The discrete two- or three-dimensional flux distributions can then be used explicitly with microscopic cross sections to calculate fuel burnup and isotopic depletion for individual fuel rods. In more routine calculations for PWR cores, macroscopic group constants generated from unitcell calculations are used parametricaliy to determine fuel burnup for each fuel rod, and isotopic concentrations are determined from the unit-cell calculations.

In contrast, large spatial variations of moderator density, additional heterogeneities introduced by the control blades, and the enrichment distribution within each fuel assembly in BWR cores make full three-dimensionaı calculations necessary for determination of power and burnup distributions. For economic reasons, however, coarse-mesh threedimensional calculations are usually coupled with thermal-hydraulic feedback effects in BWR cores using codes such as FLARE, an and the BWR Core Simulator. ${ }^{88}$ Thus, fine-mesh calculations are necessary for one or more fuel assemblies where individual fuel rods, control blades, and other material heterogeneities are discretely represented..$^{\theta \theta}$ The macroscupic group constants from these fine-mesh assembly calculations are then used parametrically to determine global power distributions and fuel burnup distributions in coarsemesh three-dimensional calculations, and isotopic compositions are determined.

In CANDU reactor ccres, the cool heavy-water moderator surrounding the pressure tube indicates a degree of heterogeneity similar to BWR cores. In CANDU and BWR cores, group constants are generated for fuel buudles; in PWR cores, the group constants are generated for individual fuel rods. The few-group constants generated from the bundle calculations (for example, based on the LATREP code $^{70}$ ) are then used in two- and three-dimensional 
diffusion theory calculations to determine power and burnup distributions.

\section{TV. RXPERIMENTAL METHODS FOR BURN- UP DETERMINATIONS}

\section{A. Burnup Distribution}

Methods available for the Experimental determination of fuel burnup are nondestructive analysis (NDA) and destructive analysis (DA).

NDA methods are described in Sec. II of the main text. Briefly, they entail gamma assay of a spentfuel assembly or rod to determine burnup; the theory is that the fission-product yield relates the number of fissions, or fuel burnup, to the amount of fission product produced. The calculation also requires the energy released per fission for each of the fissionable nuclides.

DA methods involve chemical dissolution of the spent fuel. Specific methods are mass spectroscopy and radiochemical assay. Mass spectroscopy is perhaps the most direct method because it actually measures the absolute and/or relative concentrations of the nuclides and relates them to burnup using simple equations. Two ways to relate isotopic concentrations to burnup are the heavy-element (HE) and ${ }^{140} \mathrm{Nd}$ methods. The HE method"1 determines the number of atoms present for each fissionable nuclide and, using the information on fission energy for each isotope, calculates burnup in MWD/MTU. The ${ }^{149} \mathrm{Nd}$ method ${ }^{72}$ differs from other fission-product methods because " radioactive so no correction is necessary for radioactive decay. The essential quantities are the EOC atom ratios of ${ }^{149} \mathrm{Nd}$ to fissioning nuclides, effective energy per fission, and fission yields.

\section{B. Power Distribution}

Accuracy in the fuel burnup predictions is effectively limited by the corresponding accuracy in the nower distribution predictions because fuel burnup is obtained as a time-integral of power. Hence, to evaluate accuracy of burnup predictions, accuracy of power distribution predictions is investigated. Experimental techniques used to measure power distribution in operating power reactors are reviewed; in particular, gamma-scan techniques and in-core power distribution monitoring methods are discussed.

The gamina-scan techniques (see Sec. II) involve analysis of fuel elements or assemblies for photopizaks of certain fission products. A burnup monitor must have a long half-life. For power distribution determination, instantaneous or $i$ ecent fission events are importarit, as opposed to burnup determinations where cumulative fission events are desired. Therefore, the fission product used as a power distribution monitor should have a short halflife. A commonly used isotope in this application ${ }^{7 \mathrm{~s}}$ is ${ }^{10} \mathrm{La}$, which has a half-life of $40.2 \mathrm{~h}$.

If the power distribution were held constant for 60 days (which corresponds to about five half-lives of ${ }^{140} \mathrm{Ba}$, whose decay product is ${ }^{100} \mathrm{La}$ ) the spatial distribution of the ${ }^{140} \mathrm{La}$ gamma activity is assumed to be directly proportional to the power distribution. To be more accurate, however, the actual power distribution history during the two months of operation before shutdown is closely simulated by diffusion theory calculations, and the predicted ${ }^{140} \mathrm{La}$ activity distribution is compared with the measured distribution. The accuracy in predicting the ${ }^{140} \mathrm{La}$ can then be interpreted as the accuracy in the power distribution predictions. ${ }^{74}$

Movable and/or fixed in-core neutron detectors are used in LWR cores to determine three-dimensiunal power maps at operating conditions. ${ }^{75 \cdot 77}$ Miriature fission chambers or self-powered neutron detectors nornally are used in power distribution monitoring systems. The movable detector system provides spatially continuous axial power distributions at discrete time intervals, whereas the fixed detector system yields timewise continuous information at a few discrete spatial points. In some older cores, either flux wire or aeroball activation systems were also used.

It is a general practice to deduce from the detector signals the average power distribution in the assembly or assemblies surrounding each detector. This conversion to assembly-average power distribution is based on the power-to-detector signal ratios obtained from the multigroup diffusion theory calculations. Power distribution in uninstrumented assemblies is obtained from interpolations and/or extrapolations of the measured power distribution 
in instrumented assemblies, again based on the calculated assembly power distribution. Local pinto-pin power distributions from multigroup diffusion theory calculations are then superimposed on the assembly power distribution tc obtain a global pin-to-pin power distribution in the $x-y$ plane. For movable detector systems, the measured axial power distributions are coupled with this $x-y$ distribution to obtain a three-dimensional power map. ${ }^{78}$ For a fixed detector system, axial power distributions are generated by Fourier analysis of discrete detector signals, and then combined with the $x-y$ power distribution as in the movable detector system. ${ }^{77}$

\section{ACCURACY IN BURNUP PREDICTIONS}

To better understand the usefulness of burnup predictions for nuclear safeguards purposes, we will summarize burnup prediction capabilities of PWR, BWR, and CANDU reactors. The discussions concentrate on accuracy of predicting burnup and power distributions (assembly average, relative rodto-assembly, and relative axial within rod), and isotopic distributions for ${ }^{236} \mathrm{U}$ and fissile plutonium isotopes (assembly average and relative rod-wise within assembly). The accuracy of these predictions is evaluated in terms of the standard deviation of relative errors between calculational and experimental values, based on comparisons from the open literature. In many cases, standard deviations were generated using published raw data. In some cases, because the limited number of data points did not warrant meaningful calculations of standard deviations, only the range of accuracy is reported. Discussions on the accuracy of the data bases are presented, followed by a summary in Table A-I.

\section{A. PWR}

1. Burnup Distribution. Most available data on burnup distribution predictions are from two older reactors, Yankee-Rowe and Trino-Vercellese. Both reactors are relatively small but they are well documented.

Accuracy of assembly-averaged burnup predictions ranges from a $\pm 3 \%$ standard deviation for
Trino $^{78}$ to $\pm 4.7 \%$ for Yankee-Rowe. ${ }^{59}$ Values of $\pm 3.5 \%$ (Ref. 79 ), $\pm 3.8 \%$ (Ref. 80 ), and $\pm 3.9 \%$ (Ref. 81) were found in Yankee evaluations. An independent evaluation ${ }^{82}$ on Yankee data also indicates a $\pm 3.8 \%$ standard deviation. The $4.7 \%$ value should not be regarded toc highly because it was determined by a coarse-mesh description in the FLARE code; the other PWR calculations were performed using fine-mesh diffusion theory codes. A typical estimate of the experimental error for assemblyaverage burnup determination is $\pm 5 \%$ (Ref. 79) for both radiochemical $\left({ }^{197} \mathrm{Cs}\right)$ and heavy-element evaluations.

Relative rod-to-assembly data are somewhat scarce. A $\pm 1.1 \%$ standard deviation was obtained ${ }^{17}$ for the Trino reactor. $A \pm 1.7 \%$ rod-to-assembly standard deviation was found for two fuel assemblies from the Beznau reactor. ${ }^{\text {ss }}$ There was no estimate of the accuracy of experimental methods for this particular category, but data snould not deviate significantly from that on an assembly-wise or local axial basis. Calculational accuracy in predicting relative axial burnup distributions within rods is available for Trino spent-fuel studies. Values obtained are $\pm 3.8 \%$ (Ref. 78 ) and $\pm 5.0 \%$ (Ref. 17 ). The experimental accuracy in determining the local burnup distributions appears to depend somewhat on the method used. Typical results are $\pm 4 \%$ for heavy element, ${ }^{78} \pm 2 \%$ for neodymium, ${ }^{17}$ and $\pm 5 \%$ for ${ }^{137} \mathrm{Cs}$ methods. ${ }^{17}$

2. Power Distribution. For assembly power distributions, reports indicate a \pm 2 to $3 \%$ standard deviation for reactor cores made by Combustion Engineering, Inc., ${ }^{77,84-87}$ and \pm 1.6 to $3.3 \%$ for the Trino. ${ }^{88}$ Similarly, a $\pm 2.3 \%$ standard deviation was obtained in predictions of assembly-averaged power distribution for the Kewaunee reactor ${ }^{89}$ For the San Onofre reactor, power distributions were measured experimentally by aeroball activation, and a $\pm 6.2 \%$ standard deviation in assembly-averaged power distribution prediction was reported..$^{20}$ However, a \pm 5 to $9 \%$ standard deviation in the experimental measurement of assembly-averaged power distribution was estimated by Fenech for the aeroball system." Thus, the somewhat large $\pm 6.2 \%$ standard deviation reported for the San Onofre reactor seems to be partly from inaccuracies in the aeroball system itself, and is not included in Table A-I. For other 


\section{TABLE A-I}

\section{FUEL BURNUP PREDICTION ACCURACY}

\begin{tabular}{l}
\multicolumn{3}{c}{ Standard Deviation (y) } \\
\hline$\underline{\text { PWR }}$ BWR
\end{tabular}

Burnup Distribution

Assembly average

Relative rod-to-assembly

Relative axial within rod

Power Distribution

Assembly average

Relative rod-to-assembly

Relative axial within rod

Isotopics Distribution

$\begin{array}{cc}3-5 & (3-5)^{b} \\ 1-2 & 2-4 \\ 4-5 & 6\end{array}$

$\begin{array}{cccc}\begin{array}{c}\text { Assembly average } \\ \text { 2as }\end{array} & 5 & (5-10) & (5-10) \\ \begin{array}{c}\text { Fissile Pu } \\ \text { Relative rod-to-assembly } \\ \text { s"s }\end{array} & 5 & (5-10) & (5-10) \\ \text { Fissile Pu } & 5 & 5 & 5^{\text {c }} \\ & 8 & 4 & 5^{c}\end{array}$

$\begin{array}{ccc}2-4 & 3-5 & 4 \\ 1-4 & 1-6 & 4^{\mathrm{c}} \\ (5-10) & 4-9 & (5-10)\end{array}$

-Standard deviation between calculational and experimental values divided by experimental value.

'Numbers in parentheses indicate best estimates.

cIndicates ranges of error only.

reactors, better experimental sccuracy is expected because in-core neutron detectors and/or flux wire activations were used to determine power distributions experimentally.

Ariemma et al. ${ }^{\text {so }}$ reported \pm 0.8 to $3.4 \%$ standard deviation in their predictions of relative power distribution within assemblies, based on analyses of Saxton critical facilities data.

3. Isotopics Distribution. Most available data on isotopics distributions are also from YankeeRowe and Trino. Although the Yankee evaluations were quite extensive and included a careful evaluation on experimental accuracy in assemblyaveraged isotopics distributions, no comparison bet- ween calculations and measurements can be found in the literature. However, a recent evaluation by Swedish researchers ${ }^{02}$ ircludes some isotopics comparisons.

On an assembly-averaged basis, standard deviations of $\pm 4.1 \%$ for ${ }^{236} \mathrm{U}$ and $\pm 4.3 \%$ for fissile plutonium concentrations were obtained ${ }^{82}$ as an indication of calculational accuracy for Yankee-Rowe. Similarly, standard deviations of $\pm 3.8 \%$ for ${ }^{295} \mathrm{U}$ and $\pm 4.0 \%$ for fissile plutonium concentrations were generated for Trino. ${ }^{72}$ Standard deviations of $\pm 1.0 \%$ for ${ }^{238} \mathrm{U}$ and $\pm 1.6 \%$ for fissile plutonium concentrations in the experimental isotopics determination on an assembly-wise basis were obtained from the Yankee evaluations. ${ }^{79}$ 
Absolute isotopics comparisons for the local axial distributions within fuel rods were presented in a report on Trino spent fuel, ${ }^{17}$ which suggests standard deviations of $\pm 5.5 \%$ for ${ }^{295} \mathrm{U}$ and $\pm 8.3 \%$ for fissile plutonium as tìe calculational accuracies. If the errors in the assembly-averaged isotopics calculations reported for Trino, that is, $\pm 3.8 \%$ for ${ }^{235} \mathrm{U}$ and $\pm 4.0 \%$ for fissile plutonium, are not included in the abuve absolute local isotopics errors, we obtain a conservative estimate of isotopics calculational errors of relative rod-wise distributions within fuel assemblies as $\pm 4.0 \%$ for ${ }^{295} \mathrm{U}$ and $\pm 7.3 \%$ for fissile plutonium concentrations. Evaluations of the Yankee-Rowe isotopics ${ }^{82}$ iridicate calculational errors of 1.4 to $2.8 \%$ for ${ }^{23 s} \mathrm{U}$ and 0.3 to $3.4 \%$ for fissile plutonium concentrations.

\section{B. BWR}

1. Burnup Distribution. As for PWRs, avail.ble information on burnup distribution for BWRs is based on a limited number of studies. The BWRs most extensively studied are Garigliano and the Japanese Power Demonstration Reactor (JPDR). The former approaches typical commercial size, whereas the latter, as the name implies, is a small demonstration reactor.

Relative rod-to-assembly burnup distributions calculated for Garigliano ${ }^{20}$ show a 1.5 to $3.4 \%$ standard deviation compared with the experiment. For this study the gamma-scan technique was used, with ${ }^{137} \mathrm{Cs}$ as a burnup monitor. The gamma scan results showed relative burnup distributions, which were later calibrated to DA results using the ${ }^{14 \theta} \mathrm{Nd}$ method.

Relative axial-to-rod burnup distributions estimated $^{30}$ for JPUR-1 produced a $\pm 5.9 \%$ standard deviation. The experiniental methods were as outlined above, that is, gamma scan plus DA. This method has an accuracy, on a local iasis, of $\pm 3.5 \%$ (Ref. 20).

2. Power Distribution. There is more information for power distributions in BWRs than for burnup distributions. Other reactors providing data are: Jersey Central, KKM, KRB, Tsuruga, Quad Cities Unit 1, and Dodewaard.
Values for the standard deviation of assembly power range from $\pm 2.1 \%$ (Ref. 92 ) to $\pm 4.5 \%$ (Ref. 93). The low $2.1 \%$ is for a group of four adjacent assemblies. Most recent results indicate a range of \pm 2.4 to $3.5 \%$ (Refs. 74,94 ), based on studies done for several operating BWRs mentioned above. The $\pm 2.4 \%$ accuracy by Carew $^{94}$ is hased on a fine-mesh diffusion theory calculation, whereas the \pm 2.4 to $3.5 \%$ standard deviation by Parkos 74 is based on standard coarse-mesh three-dimensional calculations. The usual experimental method is gamma scanning of ${ }^{140} \mathrm{La}$ activities.

The calculational accuracy of relative rod-toassembly power distributions in BWRs was well represented recently, ${ }^{\theta 8}$ and calculational errors from \pm 1 to $6 \%$ were reported, based on an analysis of Jersey Central, KRB, and Tsuruga. This range is within previously reported values of $\pm 3.5 \%$ (Ref. 94 ), $\pm 4.2 \%$ (Ref. 92 ), $\pm 1.3 \%$ (Ref. 95 ), and $\pm 4.6 \%$ (Ref. 96).

A recent study 7 suggests standard deviations from \pm 3.7 to $8.3 \%$ for the accuracy in calculating axial power peaking factors for individual fuel assemblies in BWR cores, as compared to gammascan results. Although these error estiniates are considered somewhat optimistic for relative axial power distribution calculation in BWR cores, they have been included without subjective bias introduced by the authors. The experimental error for the gammascan measurements based on ${ }^{140} \mathrm{La}$ distribution is \pm 2 to $3 \%$ (Ref. 73 ).

3. Isotopics Distribution. Prediction capability for assembly-averaged uranium and plutonium fissile content is not readily available. However, there are data that compare rod-to-assembly predictions and experiments. Calculational results were compared with mass spectrometric results for a chosen $x-y$ plane in Garigliano. ${ }^{20}$ 'The study indicated a standard deviation of $\pm 4.5 \%$ for ${ }^{205} U$ and a $\pm 4 \%$ standard deviation for determination of fissile plutonium content.

\section{CANDU}

1. Burnup Distribution. The concept of spatially varying burnup distributions from one 
assembly to another is less meaningful when applied to CANDU because of continuous refueling. "77 Fuel bundles are continuously moved in the reactor, and burnup predictive capability at a given point is less useful. The quantity usually noted in CANDU literature is the equilibrium discharge burnup, which is the operator's goal for each bundle. Calculations to determine this quantity have yielded accuracy to $\pm 2 \%$ for $7000 \mathrm{MWD} / \mathrm{MTU}$, and epproximately $\pm 5 \%$ for $7000 \mathrm{MWD} / \mathrm{MTU}$ for the NPD reactor. Experimental data for such comparisons were from DA, where the calculated ${ }^{295} \mathrm{U}{ }^{239} \mathrm{U}$ atom ratios were normalized to the experimental values. Hence, because these error estimates are considered optimistic, a $2 \%$ error has been added arbitrarily to obtain more realistic error estimates for bundle-average burnup predictions.

Calculations based on the isotopics data presented for the NPD reactor, ${ }^{98}$ the heavy-element methud, ${ }^{71}$ and typical nuclear parameters ${ }^{24}$ yielded an approximate estimate on prediction accuracy of the relative rod-to-assembly burnup distribution from \pm 1 to $2 \%$.

2. Power Distribution. Comparisons of calculated and measured channel power distributions for the Douglas Point reactor indicate a $\pm 4 \%$ standard deviation. ${ }^{99}$ Channel power in CANDU is the power produced by all the bundles in a pressure tube and hence, is equivalent to the assemblyaveraged pcwer in LWR cores.

Thermal neutron flux distributions from CANDU compared with calculations ${ }^{100}$ indicate that axial peaking fuctors within assemblies could br. calculated to a $1.6 \%$ accuracy. This accuracy, however, orly refers to the peaking fuctors within short bundles. An overall axial power distribution calculation is expected to be much less accurate. Similarly, the calculation of the relative rod-tobundle thermal flux distribution has been shown to lie within $3.3 \%$ of experimental results. These calculations were made using a two-dimensional transport theory code.

3. Isotopics Distribution. The results from isutopics studies ${ }^{\text {os }}$ done on an assembly-wise basis were only from the ${ }^{2 s 5} \mathrm{U} /{ }^{2 s a} \mathrm{U}$ atom ratios normalized to the experimental values. Errors of the relative rod-to-bundle isotopics calculation range up to $\pm 4.5 \%$ for ${ }^{23} \mathrm{U}$ and $\pm 4.3 \%$ for fissile plutonium concentration.

\section{Summary}

Discussions in this section are based on published information and are summarized in Table A-I, where we round off the available error estimates to the next larger integer values. Whenever actual data exist, the published information has been presented in an attempt not to introduce subjective estimates. When no actual data were available, best estimates were provided in parentheses.

Because experimental errors involved in the various burnup and power distribution measurements have not been accounted for explicitly, the fuel burnup prediction accuracies summarized in Table A-I are only relative to measurements and are by no means absolute accuracies. Also, most of our information is based on bench-mark calculations on burnup, power, and isotopics distributions. Thus, the accuracy estimates in Table A-I may often represent rather optimistic estimates on burnup prediction capability.

\section{CONCLUDING REMARKS}

We have presented reasonable estimates on the fue] burnup prediction capabilities for LWR and CANDU, based on published results (mostly from bench-mark calculations). These calculations are invariably performed with detailed simulations of the actual operating history of the plants, including control poison variations. For nuclear materials safeguards, however, it is important to verify declared fuel burnup based on predicted calculations performed without detailed simulations of the plant operating history.

An estimate of the error bounds for burnup prediction calculations without detailed simulations of the actual operating history might be obtained by studying changes in power distributions caused by power level changes and/or control rod motions. Thus, in PWR cores, a maximum difference of $7 \%$ in assembly-averaged power distribution may be observed between hot full-power conditions with and without equilibrium xenon poisoning. ${ }^{101}$ This $7 \%$ 
difference would represent an upper bound on the expected changes in the assembly-averaged power distribution caused by power plant operations at less than full-power levels. Thus, an additional error from 5 to $7 \%$ in the assembly-averaged burnup distributions might be suggesled to account for the lack of detailed simulations of the plant operating data.

Without detailed simulations of the operating data, somewhat larger errors could be expected for predicted axial burnup distributions in individual fuel assemblies or rods because of the tilting of axial power distributions under the presence of negative moderator temperature coefficients in PWR cores, that vary as a function of power level. Relative rodwise burnup distributions within fuel assemblies are not expected to change significantly because of power level changes.

In BWR cores, control blades are interchanged and gradually removed in a sequential manner as a function of core fuel burnup, in contrast to PWR cores which are normally operated without insertion of any control rods. Thus, a substantial error could be made in predicting burnup distributions in BWR cores if detailed control rod histories are not simulated.

In PWR cores, average power in a fuel assembly could change by $\sim 35 \%$ by the insertion or removal of an adjacent con:rol blade. ${ }^{102}$ Control blades, however, usually are rotated among a group of four adjacent units to match predicted Haling power distributions as closely as possible. ${ }^{103}$ Perhaps a maximum additional error of $\sim 10$ to $15 \%$ in the assembly-averaged burnup predictions might be suggested for BWR cores where detailed control rod histories are not simulated. Substantially larger errors in burnup predictions for relative rod-toassembly and axial distributions could possibly be expected in BWR cores if detailed simulations are not made of contro! rod motions, power levels, and/or flow distributions.

Burnup predictions based on in-core power distribution measurements should be used whenever possible to provide additional verification of declared fuel burnup. There should be increased emphasis on assessment of the occuracy of the power distribution monitoring sysiems so that they will be more meaningful for control of nuclear materials.

\section{REFEKENCES}

1. E. R. Edwards, "A Review of Recent Studies of Nondestructive Assay Methods for Irradiated Nuclear Fuel," Nucl. App. 4, 245-259 (1968).

2. T. N. Dragnev, "Experimental Techniques for Measuring Burn-up Non-destructive Techniques: Gamma Spectroscopy," International Atomic Energy Agency report IAEA/STR-48 (October 1974).

3. R. S. Forsyth, W. H. Blackadder, and N. Ronquist, "Burn-up Determination by High-Resolution Gamma Spectrometry: Fission Product Migration Studies," Aktiebolaget Atomenergi (Sweden) report AE-272 (April 1967).

4. J. R. Phillips, "New Techniques in Precision Gamma Scanning, Application to Fast-Breeder Reactor Fuel Pins," Los Alamos Scientific Laboratory report LA-5260-T (July 1973).

5. J. R. Phillips, G. R. Waterbury, N. E. Vanderborgh, and T. K. Marshall, "Quantitative Determination of Fission Products in Irradiated Fuel Pins Using Nondestructive Gamma Scanning," Anal. Chem. 47, 71-75 (1975).

6. J. E. Rein, "Status of Burnup Measurement Methodology," in Anal. Meth. in the Nucl. Fuel Cycle, Proc. Symp., Vienna, November 29-December 3, 1971 (International Atomic Energy Agency, Vienna, 1972), Paper SM-149/40, pp. 449-472.

7. R. W. Durham, "Burnup of Ceramic Fuel by Gamma-Ray Scanning," Atomic Energy of Canada Limited report AECL-2688 (Aprii 1967).

8. D. G. Boase, J. D. Chen, and L. T. Felawka, "Gamma Spectrometry of Irradiated Reactor Fuels, 
Experience at the Whiteshell Nuclear Research Establishment," Atomic Energy of Canada Limited report AECL-3952 (October 1971).

9. J. R. Phillips, G. R. Waterbury, and G. E. Vanderborgh, "Distributions of ${ }^{194} \mathrm{Cs}$ and ${ }^{197} \mathrm{Cs}$ in the $\mathrm{Ax}$ ial $\mathrm{UO}_{2}$ Blankets of Irradiated (U,Pu) $\mathrm{O}_{2}$ Fuel Pins," J. Inorg. Nucl. Chem. 36, 17-23 (1974).

10. S. Hiller, "Gamma-Spectrometric Burnup Determination in Reactor Fucl Rods," Kerntechnik 12; No. 11, 485-490 (1970).

11. J. L. Bates, "Fission Product Distribution in Irradiated $\mathrm{UO}_{2}, "$ Battelle Pacific Northwest Laboratory report BNWL.58 (March 1965).

12. G. Adiletta, N. Benatti, R. Guidotti, M. Paoletti Gualandi, P. Peroni, A. M. Bresesti, M. Bresesti, and D. D'Adamo, "Investigations on Radioactive Fission Product Correlations: Gamma Spectrometry Measurements on Spent Fuel Assemblies of the Garigliano Reactor," Joint Nuclear Research Centre (Ispra) report EUR-5289e (1974).

13. H. Hick and M. Lammer, "Interpretation of Gamma Spectrometric Measurements on Burnt Fuel Elements," in Safeguards Techniques, Proc. Symp., Karlsruhe, July 6-10, 1970 (International Atomic Energy Agency, Vienna, 1970), Paper IAEASM-133/5, Vol. I, pp. 533-537.

14. T. Dragnev and C. Beets, "Identification of Irradiated Fuel Elements," Euratom report EUR4576e, Karlsruhe report KFK 1100, Chap. 3, Joint Integral Safeguards Experiment (JEX 70) at the Eurochemic Reprocessing Plant, Mol, Belgium (January 1970-July 1971).

15. J. Valovic, V. Petenyi, S. B. Rana, D. Mikusova, and J. Kmosena, "The Application of Gamma and Irotopic Correlation Techniques for Safeguards Identification and Verification Purposes," final report, International Atomic Energy Agency research contract 1443 , Bohunice Nuclear Power Plant, Bohunice, Czechoslovakia (1975).

16. R. S. Forsyth and W. H. Blackadder, "Use of the Fission Product ${ }^{108} \mathrm{Ru}$ Gamma Activity as a Method for Estimating the Relative Number of Fission Events in ${ }^{238} \mathrm{Pu}$ in Low-Enriched Fuel Elements, " in Safeguards Techniques, Proc. Symp., Karlsruhe, July 6-10, 1970 (International Atomic Energy Agency, Vienna, 1970), Paper IAEA-SM-133/4, Vol. I, pp. 521-532.

17. A. M. Bresesti, M. Bresesti, S. Facchetti, F. Mannone, P. Barbero, C. Cerutti, F. Marell, A. Peil, R. Pietra, R. Klersy, A. Schürenkämper, A. Frigo, E. Ghezzi, J. P. Meerschman, A. Pollicini, K. H. Schrader, J. Biteau, A. Cricchio, and L. Koch, "Post-Irradiation Analysis of Trino Vercellese Reactor Fuel Elements, " Joint Nuclear Research Centre (Ispra and Karlsruhe) report EUR-4909e (1972).

18. P. Brand, A. Cricchio, and L. Koch, "Feasibility Study of the Use of Radioactive Fission Product Correlations for the Determination of Burnup and Heavy Isotopes Composition of BWR Dodewaard Fuel," Joint Nuclear Research Centre (Karlsruhe) report EUR-5141e (1974).

19. P. Barbero, G. Bidoglio, M. Bresesti, R. Chevalier, D. D'Adamo, S. Facchetti, A. Federici, G. Guzzi, L. Lezzoli, F. Mannone, F. Marell, P. R. Trincherini, G. Buscaglia, A. Drago, R. Faccelli, A. Frigo, E. Ghezzi, R. Klersy, K. H. Schrader, A. Schüerenkäemper, R. Dierckx, J. Biteau, G. Cottone, A. Cricchio, L. Koch, R. Bannella, M. Paoletti Gualandi, and $\boldsymbol{P}$. Peroni, "Post Irradiation Examination of the Fuel Discharged From the Trinc Vercellese Reactor After the 2nd Irradiation Cycle," Joint Nuclear Research Centre (Ispra and Karlsruhe) and Ente Nazionale for l'Energia Electtrica-Rome (Italy) report EUR-5605e (1976).

20. A. Ariemma, L. Bramati, M. Galliani, M. Paoletti Gualandi, B. Zaffiro, A. Cricchio, and L. Koch, "Experimental and Theoretical Determination of Burnup and Heavy Isotope Content in a Fuel Assembly Irradiated in the Garigliano Boiling Water Reactor," Ente Nazionlae per l'Energia Electtrica-Rome (Italy) report EUR-4638e (1971).

21. R. Bannella, A. Giuriato, M. Paoletti Gualandi, A. M. Bresesti, M. Bresesti, D. D'Adamo, "Relative Measurements of Burnup and Plutonium Content 
in PWR Assemblies," Trans. Am. Nucl. Soc. 15, 681682 (1972).

22. A. M. Bresesti, M. Bresesti, M. Cuypers, D. D'Adamo, L. Lezzoli, R. Bannella, A. Giuriato, M. Paoletti Gualandi, and P. Peroni, "Investigations on Radioactive Fission Product Correlations: Gamma Spectrometry Measurements on Spent Fuel Assenblies Discharged from the Trino Vercellese Reactor at the End of the 2nd Irradiation Cycle," Joint Nuclear Research Centre (Ispra) and Ente Nazionale per l'Energia Electtrica-Rome (Italy) report EUR-5334e (1975).

23. M. Paoletti Gualandi, P. Peroni, M. Bresesti, M. Cuypers, D. D'Adamo, L. Lezzoli, "Determination of Burnup and Plutonium Content in Irradiated Fuels by Gamma-Spectrometry Measurements of Radioactive Fission Products," in Safeguarding Nuclear Materials, Proc. Symp., Vienna, October 20-24, 1975 (International Atcmic Energy Agency, Vienna, 1976), Vol. II, Paper IAEA-SM-201/3, pp. 613-624.

24. J. D. Chen, D. G. Boase, and R. B. Lypka, "Non-destructive Determination of Burn-up by Gamma-Scanning: an Assessment of ${ }^{14} \mathrm{Ce} / \mathrm{Pr}$ as a Fission Monitor in CANDU Fuels," Atomic Energy of Canada Limited report AECL-5236 (January 1976).

25. R. L. Heath, "The Potential of High-Resolution Gamma-Ray Spectrometry for the Assay of Irradiated Reactor Fuel," Safeguards Res. Devel., Proc. Symp. Argonne National Laboratory, June 26, 1967, report WASH-1076, pp. 115-129 (1967).

26. H. G. Mehner, "Bestimmung der Relativen Effektivität in $\gamma$-Spektrometrischen Abbrandmeßeinrichtungen," Kernenergie 19, No. 1, 3-5 (1976).

27. C. Beets, P. Bemelmans, and R. Pirard, "Gamma Measurements on SENA Spent Fuel Assemblies and Dissolver Solutions," Contributions to the Joint Safeguards Experiment Mol IV at the Eurochemic Reprocessing Plant, Mol, Belgium, report BLG-486 (September 1973).
28. T. N. Dragnev, "Intrinsic Self-Calibration of Nondestructive Gamma Spectrometric Measurements (Determination of $\mathrm{U}, \mathrm{Pu}$, and Am-241 Isotopic Ratios)," International Atomic Energy Agency report IAEA/STR-60 (August 1976).

29. S. Matsuura, H. Tsuruta, T. Suzaki, H. Okashita, H. Umezawa, and H. Natsume, "Nondestructive Gamma-Ray Spectrometry on Speni Fuels of a Boiling Water Reactor," J. Nucl. Sci. and Technol. 12, 24-34 (1975).

30. H. Natsume, S. Matsuura, H. Okashita, H. Umezawa, and H. Ezure, "Gamma-Ray Spectrometry and Chemical Analysis on JPDR-1 Spent Fuels," Japan Atomic Energy Research Institute report JAERI-memo-6291 (October 1975).

31. C. Foggi, F. Frenquellucci, and G. Perdisa, "Isotopic Correlations Based on Fission-Product Nuclides in LWR Irradiated Fuels, a Theoretical Evaluation," in Safeguarding Nuclear Materials, Proc. Symp., Vienna, October 20-24, 1975 (International Atomic Energy Agency, Vienna, 1976), Vol. II, Paper IAEA-SM-201/44, pp. 425-438.

32. L. Leenders, "Contribution to the Investigation of Isotopic Correlations Among Non-destructive Measurements on Fuel Rods," Contributions to the Joint Safeguards Experiment Mol IV at the Eurochemic Reprocessing Plant, Mol, Belgium, report BLG-486 (September 1973).

33. C. Beets, P. Bemelmans, T. Dragnev, and R. Hecq, "Gamma Measurements on Spent Fuel Elements," Trans. Am. Nucl. Soc. 15, 673-674 (1972).

34. N. C. Rasmussen, J. A. Sovka, ard S. A. Mayman, "The Non-destructive Measurement of Burn-up by Gamma-Ray Spectroscopy, " in Nuclear Materials Management, Proc. Symp., Vienna, August 30-September 3, 1965 (International Atomic Energy Agency, Vienna, 1966), Paper IAEASM-67/45, pp. 829-849.

35. C. K. Tzou and C. M. Yang, "Nondestructive Burnup Determination by Gamma-Ray Spectroscopy," Nucl. Technol. 24, 246-251 (1974). 
36. T. N. Dragnev, M. deCarolis, A. Keddar, Yu. Konnov, G. Martinez-Garcia, A. J. Waligura, "Some Agency Contributions to the Development of Instrumental Techniques in Safeguards," in Safeguarding Nuclear Materials, Proc. Symp., Vienna, October 20-24, 1975 (Internationai Atomic Energy Agency, Vienna, 1976), Paper IAEA-SM201/96, Vol. II, pp. 37-62.

37. P. J. Kreyger, R. J. S. Harry, H. Ḱruckei, "Nondestructive Burn-up Determination by $145-\mathrm{keV}$ Gamma-Ray Absorption," in Safeguards Techniques, Proc. Symp., Karlsruhe, July 6-10, 1970 (International Atomic Energy Agency, Vienna, 1970), Paper IAEA-SM-133/6, Vol. I, pp. 545-550.

38. T. Gozani, "Active Direct Measurement of Residual Fissile Content in Spent Fuel Assemblies," Electric Power Research Institute report EPRI 278-1 (July 1975).

39. T. Gozani, "Non-destructive Assay of Spent Fuel for Determination of Residual Fissile Content," Proc. 17th Annual Meeting of the Institute of Nucl. Mater. Manage., Seattle, Washington, June 22-24, 1976, pp. 514-524.

40. H. O. Menlove, Los Alamos Scientific Laboratory, personal communication, May 1977.

41. G. L. Ragan, R. S. Booth, T. J. Burns, J. D. Jenkins, C. R. Weisbin, and L. R. Williams, "System for Assay of Fissile Content of Spent LMFBR Fuel Subassemblies," Trans. Am. Nucl. Soc. 23, 95-96 (1976).

42. K. Baumung, K. Böhnel, J. Klunker, M. Küchle, a.dd J. Wolff, "Investigations into Nondestructive Safeguards Techniques," in Safeguards Techniques, Proc. Symp., Karlsruhe, July 6-10, 1970 (International Atomic Energy Agency, Vienna, 1970), Paper IAEA-SM-133/90, Vol. II, pp. 177-193.

43. R. H. Augustson, H. O. Menlove, D. B. Smith, A. L. Bond, D. C. Durrill, W. P. Hollowell, and C. P. Bromley, "An Automated Nondestructive Assay System for the Measurement of Irradiated Rover Fuel," Proc. 16th Annual Meeting of the Institute of
Nucl. Mater. Manage., New Orleans, Louisiana, . Tune 18-20, 1975, pp. 152-166.

44. P. Filss, "Non-destructive Control of Fissile Material Containing Radioactive Fission Products with a Sb-Be-Neutron Source by Selective Transport of Fission Neutrons in Hydrogeneous Material," Kernforschungsanlage Julich report Jul1046-CT (February 1974).

45. P. Filss, "Non-destructive Control of Fissile Material in Solid and Liquid Samples Arising from a Reuctor and Fuel Reprocessing Plant," in Safeguarding Nuclear Materials, Proc. Symp., Vienna, October 20-24, 1975 (International Atomic Energy Agency, Vienna, i976), Paper IAEA-SM201/53, Vol. II, pp. 471-484.

46. C. R. Weisbin, R. H. Augustson, J. S. Hendricks, A. E. Evans, and G. D. Turner, "Nondestructive Assay of Power Reactor Fuel Assemblies," Nucl. Technol. 15, 455-461 (1972).

47. R. H. Augustson, C. N. Henry, and C. R. Weisbin, "Measurement of the Uranium-235 Content in a Spent MTR Fuel Element Using the Delayed-Neutron Yield Technique," Nucl. Technol. 4, 197-199 (1972).

48. W. Rotter, "Determination of Burn-up of Irradiated Fuel Elements by Pulsed Neutron Interrogation," Ann. Nucl. Sci. Eng. 1, $451-458$ (1974).

49. H. Krinninger, S. Wiesner, and C. Faber, "Pulsed Neutron Method for Non-destructive and Simultaneous Determination of the ${ }^{295} \mathrm{U}$ and ${ }^{298} \mathrm{Pu}$ Contents of Irradiated and Non-irradiated Reactor Fuel Elements," Nucl. Instrum. Methods 73, 13-33 (1969).

50. M. P. Navalkar, K. Chandramoleshwar, and D. V. S. Ramakrishna, "A Feasibility Study of Nondestructive Assay of Pu-239 and U-235 in Irradiated Samples Using Slowing Down Time Lead Spectrometer," Nucleonik 11, No. 1, 54-56 (1968).

51. H. Krinninger and E. Ruppert, "Operational Experience with the Automatic Lead Spectrometer 
Facility for Nuclear Safeguards," Trans. Am. Nucl. Soc. 15, 683-684 (1972).

52. H. G. Priesmeyer and M. Harz, "Isotopic Assay in Irradiated Fuel by Neutron Resonance Analysis," in Safeguarding Nuclear Materials, Proc. Symp., Vienna, October 20-24, 1975 (International Atomic Energy Agency, Vienna, 1976), Paper IAEA-SM201/4, Vol. II, pp. 625-632.

53. L. N. Lazarev, "Nondestructive Methods of Analysis of the Nuclear Fuel of Fast Neutron Reactors," in LMFBR Fuel Reprocessing, Proc. Symp., Leningrad, May 17-21, 1976 (International Atomic Energy Agenry, Vienna, 1976), US Energy Research and Development Administration report ERDATR-205.

54. J. R. Beyster, "Evaluation of Reactivity Methods of Nuclear Materials Assay," Brookhaven National Laboratory report BNL-50251 (T-584) (June 1970).

55. L. Green, J. T. Kriese, and M. Natelson, "The Reactivity Perturbation Assay of Irradiated Fuel Rods," Nucl. Technol. 32, 186-204 (1977).

56. J. A. Vreeland, "Assay Capabilities of a Reactor Fuels Measurement Facility," Westinghouse Electric Corporation report WCAP-6041 (December 1959).

57. R. Ramthun and K. Debertin, "Burn-up Determination of Irradiated Fuels by Means of .Their Heat Output," Atomkernenergie 19, No. 1, 17-22 (1972).

58. K. Debertin and H. Ramthun, "Burn-up Determination of Irradiated Fuels by Means of Their Heat Output," Atomkernenergie 21, No. 2, 119-122 (1973).

59. M. Valerino and Z. Rosztoczy, "Analytical and Experimental Methods of Determining HeavyIsotope Content of Operating Fuel Elements," Combustion Engineering Incorporated report CEND-640 (September 1965).
60. Proc. Panel on Fuel Burnup Predictions in Thermal Reactors, Vienna, April 1967 (International Atomic Energy Agency, Vienna, 1968), pp. 227-240.

61. R. G. Clarke, H. J. Svoboda, V. O. Uotinen, and W. Wolkenhauer, "Status of Burnup Calculational Technology as Applied to the Nuclear Materials Safeguards Accounting System," Battelle Pacific Northwest Laboratory report BNWL-1599 (June 1971).

62. Proc. Panel on Reactor Burn-Up Physics, Vienna, July 12-16, 1971, in Reactor Burn-Up Physics (International Atomic Energy Agency, Vienna, 1973), pp. 277-291.

63. R. L. Crowther, "Methods of Fuel Management-An Overview," Am. Nucl. Soc. Conf. Mathematical Models and Computational Techniques for Analysis of Nuclear Systems (Ann Arbor, Michigan, April 9-11, 1973), CONF-730414-Pl.

64. Hydro Electric Power Commission of Ontario, Atomic Energy of Canada Limited Power Projects, "Pickering Generating Station, " report PP-4 (1969) 197-217.

65. R. Barry, "LEOPARD-A SpectrumDependent Non-spatial Depletion Code for the IBM-7094," Westinghouse Electric Corporation report WCAP-6058 (1964).

66. W. Cadwell, "PDQ-7-A Program for the Solution of the Neutron Diffusion Equations in Two Dimensions," Westinghouse Electric Corporation repori WAPD-TM-678 (1967).

67. D. Delp, D. Fischer, J. Harriman, and $M$. Stedwell, "FLARE, A Three-Dimensional Boiling Water Reactor Simulator," General Electric Company report GEAP-4518 (1964).

68. J. Woolley, "Three-Dimensional BWR Core Simulator," General Electric Company report NEDO-20953 (May 1976). 
69. C. Martin, "Lattice Physics Methods Verification," General Electric Company report NEDO20939 (June 1976).

70. G. Phillips and J. Griffiths, "LATREP User's Manual," Atomic Energy of Canada Limited report AECL-3857 (1971).

71. L. Chajson, "Yankee Core Evaluation Program Quarterly Progress Report for the Period Ending June 30, 1963," Westinghouse Electric Corporation report WCAP-6055 (July 1963).

72. A. Moncassoli-Tosi, "Burn-up Prediction for Pressurized-Water-Reactor Cores," in Reactor Burn-Up Physics, Proc. Panel on Reactor Burn-Up Physics, Vienna, July 12-16, 1971 (International Atomic Energy Agency, Vienna, 1973), 1-22.

73. M. Cutrone and G. Valby, "Gamma Scan Measurements at Quad Cities Nuclear Power Station Unit 1 Following Cycle 2," Electric Power Research Institute report EPRI-NP-214 (July 1976).

74. G. Parkos, "BWR Simulator Methods Verification," General Electric Company report NEDO. 20946 (May 1976).

75. J. J. Loving, "In-Core Instrumentation," Westinghouse Electric Corporation report WCAP. 8607 (1971).

76. C. Meyer and R. 'Stover, "In-Core Power Distribution Determination in Westinghouse Pressurized Water Reactors, "Westinghouse Electric Corporation report WCAP-8498 (1975).

77. R. Hellens and R. Ober, "A Method of Analyzing In-Core Detector Data in Power Reactors," Trans. Am. Nucl. Soc. 12, 820-821 (1969).

78. A. Moncassoli-Tosi, P. Rama, A. Bresesti, M. Bresesti, S. Facchetti, R. Klersy, F. Mannone, A. Schürenkämper, A. Cricchio, and L. Koch, "Postirradiation Burnup Analysis of TrinoVercellese Reactor Fuel Elements. Corpparison with Theoretical Results," in Reactor Burn-Up Physics, Proc. Panel on Reactor Burn-Up Physics, Vienna,
Julv 12-16, 1971 (International Atomic Energy Agency, Vienna, 1973), pp. 197-225.

79. J. Jedruch and R. Nodvik, "Experimentally Determined Burnup and Spent Fuel Composition of Yankee Core 1," Westinghouse Electric Corporation report WCAP-6071 (1965).

80. P. Lacey and R. Radcliffe, "Diffusion-Theory Depletion Analysis of the Yankee Core," Westinghouse Electric Corporation report WCAP6077 (i966).

81. R. Nodvik, "Evaluation of Gamma Activity Distributions in Yankee Core I and Core II Spent Fuel," Westinghouse Eiectric Corporation report WCADS. 6067 (June 1965).

82. D. Linstroem Jensen, "Development and Verification of Nuclear Calculation Methods for Light-Water Reactors," Danish Atomic Energy Commission, Risoe Research Establishment report RISO-235 (December 1970).

83. J. T. Dawson, "Results of Burn-Up Measurements on Two Assemblies from Beznau 1 (PWR)," Berkeley Nuclear Laboratory report RD/B/N-3239 (1975).

84. J. Humphries, A. Kadak, and R. Knapp, "OnLine Power Distribution Monitoring with In-Core Detertors," Trans. Am. Nucl. Soc. 22, 647-648 (1975).

85. W. Terney, T. Ober, and E. Williamson, "Three-Dimensional Calculational Verification of the INCA In-Core Instrumentation System with Lifetime," Trans. Am. Nucl. Soc. 22, 681-682 (1975).

86. W. Terney, G. Marks, E. Williamson, and T. Ober, "Axial Power Distributions from Fourier Fitting of Fixed In-Core Detector Powers," Trans. Am. Nucl. Soc. 22, 682-683 (1975).

87. P. Gavin and I. Rickard, "Performance of the Combustion Engineering PWR Physics Design System," Atomkernenergie 25, 87-90 (1975). 
88. A. Ariemma, G. Lesnoni La Parola, M. Puoletti Gualandi, P. Peroni, and B. Zaffiro, "Accuracy of Power-Distribution Calculation Methods for Uranium and Plutonium Lattices," Nucl. Appl. Technol. 8, 328-354 (1970).

89. Initial Startup Report, Kewaunee Nuclear Power Plant, Docket number 50305-241 (September 1974).

90. A. Impink, J. Easter, and W. Leggett, "Comparison of Predicted and Measured Nuclear Design Parameters at Beginning of Life Cycle 1 in the San Onofre Reactor," Westinghouse Electric Corporation report WCAP-3269-66 (1968).

91. H. Fenech, "Statistical Analysis of In-Core Measurements in Operating Nuclear Reactors," Trans. Am. Nucl. Soc. 15, 364-379 (1972).

92. P. L. Crowther, W. P. Petrick, and A. Weitzberg, "Three-Dimensional BWR Simulation," Proc. Conf. on the Effective Use of Computers in the Nuclear Industry, Knoxville, Tennessee, CONF690401 (April 1969).

93. T. Shimooke, "Prediction of Three-Dimensional Core Performance of JPDR (a BWR) for Burnup Cases," Nucl. Technol. 10, 257-272 (1971).

94. J. F. Carew, "Process Computer Performance Evaluation Accuracy," General Elec ${ }^{+}$ric Company report NEDO-20340 (June 1974).

95. P. G. Aline, N. H. Barth, W. R. Chancey, R. L. Crowther, D. L. Fisher, J. W. Hallam, A. Weitaberg, F. G. Warzek, and I. B. Wall, "The Physics of' Nonuniform BWR Lattices," in Physics Problems in Thermal Reactor Design (British Nuclear Energy Society, June 1967).
96. H. Bairiot, P. Devamaix, C. Vandenberg, L. Leenders, and P. Mostert, "Plutonium Assemblies in Relcad 1 of the Dodewaard Reactor," Nucl. Technol. 33, 184-202 (1977).

97. C. Miller, "Fuel Management in CANDU Reactors," Ann. Nucl. Energy 3, 359-366 (1976).

98. J. Griffiths, "The Effectiveness of LATREP Calculations: A Survey and Detailed Comparison with Experiment," Atomic Energy of Canada Limited report AECL-3739 (1971).

99. A. A. Pasanen and J. F. Blansche, "Douglas Point HWR Startup Physics Measurements and Predictions," Atomic Energy of Canada Limited report AECL-2712 (October 1967).

100. K. W. Dormuth, "Calculation of Axial Flux Distribution in CANDU Fuel Bundles," Atomic Energy of Canada Limited report AECL-5390 (1976).

101. "Reference Safety Analysis Report," Westinghouse Electric Corporation Report, RESAR 414, Vol. II, Sec. 4.3 (1976).

102. "General Electric Standard Safety Analysis Report for BWR/6," General Electric Company report GESSAR, Vol. II (1973).

103. R. K. Haling, "Operating Strategy for Maintaining an Optimum Power Distribution Throughout Life," Proc. Am. Nucl. Soc. Topical Meeting on Nuclear Performance of Power-Reactor Cores, TID-7672 (1963). 